\title{
Physicochemical techniques in description of interactions in model and native plant membranes under stressful conditions and in physiological processes
}

\author{
Elżbieta Rudolphi-Skórska ${ }^{1}$ Apolonia Sieprawska' ${ }^{1}$
}

Received: 15 April 2015/Accepted: 30 November 2015/Published online: 24 December 2015

(C) The Author(s) 2015. This article is published with open access at Springerlink.com

\begin{abstract}
The diversity of chemical structure of lipids present in the cell membranes, concerning both a hydrophilic (polarity and charge) and hydrophobic (chain length and unsaturation of fatty acids residues) parts, assists in providing suitable physical and chemical properties for the course of multiple reaction within the membrane. This review presents the results of the changes in the lipid composition of native membranes of plant cells under stress conditions and during developmental processes. It also discussed the use of lipids to create model systems which allow for interpretation of specificity of reactions taking place in the membrane fragments. The spontaneous formation by lipids closed spherical structures (bi-layers) in an aqueous medium, and monolayers at the water/air interface creates a convenient model system for the native membranes. The review focuses on the techniques of electrokinetic potential (zeta potential) measurements and Langmuir monolayers' studies. The first gives the possibility to conclude about the modification of the polar part of the membranes, the second allows to determine their structural properties (fluidity, stiffness). The relatively rapid modification of the lipid composition under stress and during the course of developmental processes to ensure the optimal functions of membranes and organelles includes the changes of hydrophobic/hydrophilic character of lipid, as an important factor influencing the course of multiple reactions in cells. Understanding the physicochemical
\end{abstract}

Communicated by A. K. Kononowicz.

Elżbieta Rudolphi-Skórska

erudolphi5@gmail.com

1 Department of Biochemistry, Biophysics and Biotechnology, Institute of Biology, Pedagogical University, Podchorążych 2, 30-084 Krakow, Poland properties of lipids that accompany these processes may contribute to the correct description of the functionality of the cells under these conditions.

Keywords Plant membranes - Lipid bilayers and monolayers - Electrokinetic potential - Langmuir technique

\section{Introduction}

Plant membranes contain various lipid species of composition changing in response to both internal and external signals. Lipids constitute a group of specific amphiphilic biomolecules. The main lipid classes of cellular membranes are neutral lipids such as sterols and polar lipids like phospholipids, glycolipids and sphingolipids, all with unique biophysical properties. The majority of these lipids are the building material of the membrane but a few have also signal-transducing properties. The molecular composition of membrane lipids differs among cell types and subcellular membrane fractions. It was suggested that there are over 1000 lipid types in membranes (Brown 2011). Table 1 presents the distribution of the main polar lipids in individual plant organelles.

Phosphatidylcholine (PC) and phosphatidylethanolamine (PE) are the major phospholipids in plasmalemma. Polar groups of both have zwitterionic character. Phosphatidylglycerol (PG) and phosphatidylinositol (PI) as well as phosphatidylserine (PS) represent a smaller fraction of membrane lipids, all with negatively charged polar groups. Monogalactolipids (MGDG) and digalactolipids (DGDG) present in chloroplast membranes in high proportions are classified as polar lipids without exposed ionic charge.

Each of polar lipids is composed of fatty acid residues varying in chain length and degree of saturation (Table 2). 


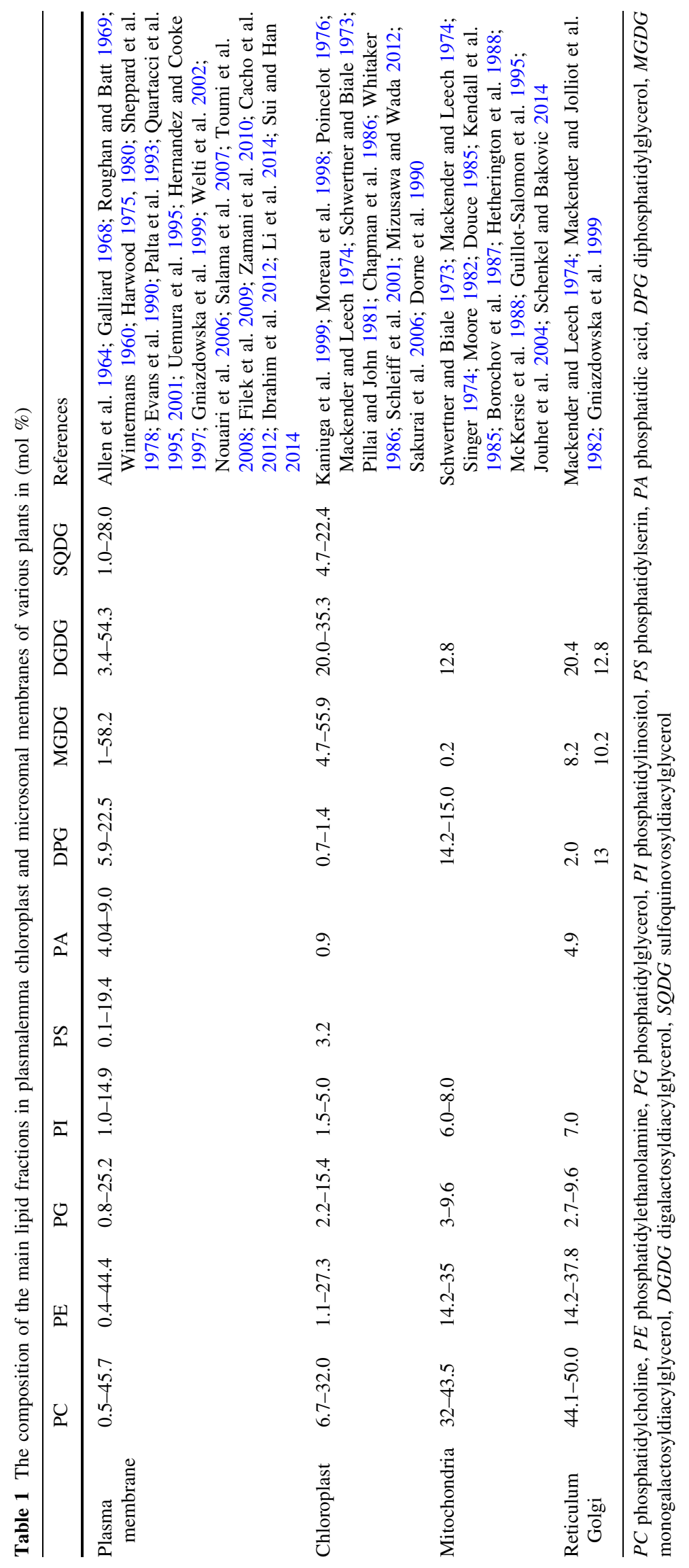


Table 2 Fatty acids compositions (16:0—palmitic acid, 18:0—-stearic acid, 18:1—oleic acid, 18:2—linoleic acid 18:3—linolenic acid) of main lipid fractions in membranes of various plants ( $\mathrm{mol} \%)$

\begin{tabular}{|c|c|c|c|c|c|c|}
\hline & $16: 0$ & $18: 0$ & $18: 1$ & $18: 2$ & $18: 3$ & References \\
\hline $\mathrm{PC}$ & $1.0-48.8$ & $0.5-32.1$ & $2.4-62.1$ & $8.6-47.0$ & $3.4-71.8$ & $\begin{array}{l}\text { Browse et al. 1986; Evans et al. 1990; Palta et al. 1993; Aziz } \\
\text { and Larher 1998; Quartacci et al. 2001; Nouairi et al. 2006; } \\
\text { Sui and Han 2014 }\end{array}$ \\
\hline $\mathrm{PE}$ & $25.2-58.0$ & $1.2-10.6$ & $1.9-13.6$ & $15.0-60.0$ & $4.6-66.5$ & $\begin{array}{l}\text { Browse et al. 1986; Aziz and Larher 1998; Evans et al. 1990; } \\
\text { Palta et al. 1993; Quartacci et al. 2001; Nouairi et al. } 2006\end{array}$ \\
\hline PG & $21.0-44.6$ & $1.9-12.0$ & $2.6-12.2$ & $6.0-36.4$ & $5.5-72.8$ & $\begin{array}{l}\text { Browse et al. 1986; Chapman et al. 1986; Quartacci et al. 1995, } \\
\text { 2001; Aziz and Larher 1998; Sui and Han } 2014\end{array}$ \\
\hline PA & $20.0-48.2$ & $6.6-21.1$ & $1.0-9.0$ & $2.0-33.1$ & $5.8-55.0$ & $\begin{array}{l}\text { Browse et al. 1986; Aziz and Larher 1998; Quartacci et al. } \\
\text { 2001; Nouairi et al. } 2006\end{array}$ \\
\hline PI & $39.9-54.6$ & $1.6-11.2$ & $1.2-7.8$ & $5.9-26.3$ & $2.9-45.3$ & Evans et al. 1990; Quartacci et al. 2001 \\
\hline PS & 38.8 & 12.3 & 11.3 & 29.0 & 6.8 & Quartacci et al. 2001 \\
\hline MGDG & $0.7-40.8$ & $0.1-27.2$ & $0.3-16.6$ & $1.0-30.1$ & 21.9-97.8 & $\begin{array}{l}\text { Browse et al. 1986; Chapman et al. 1986; Evans et al. 1990; } \\
\text { Quartacci et al. 1995; Aziz and Larher 1998; Campos et al. } \\
\text { 2003; Nouairi et al. 2006; Filek et al. 2009; Sui and Han } 2014\end{array}$ \\
\hline DGDG & $1.0-47.7$ & $0.7-19.3$ & $0.1-10.4$ & $1.2-28.5$ & $15.7-87.7$ & $\begin{array}{l}\text { Browse et al. 1986; Chapman et al. 1986; Evans et al. 1990; } \\
\text { Quartacci et al. 1995; Aziz and Larher 1998; Kaniuga et al. } \\
\text { 1999; Campos et al. 2003; Nouairi et al. 2006; Filek et al. } \\
\text { 2009; Sui and Han } 2014\end{array}$ \\
\hline SQDG & $8.0-38.6$ & $5.2-38.5$ & $5.0-15.6$ & $1.3-30.0$ & $11.3-47.0$ & Evans et al. 1990; Quartacci et al. 1995; Sui and Han 2014 \\
\hline
\end{tabular}

The degree of saturation of lipid acyl residues determines the physicochemical properties of membranes (Chapman 1975; Quinn 1988; Quinn et al. 1989), in particular the mobility of the lipid molecules. It was suggested that different functions of membrane-bound proteins depend on fatty-acid saturation degree.

The presence of lipids with various polar groups determines specific electric properties of the membrane surface whereas different composition of hydrophobic fatty acids residues is responsible for "fluidity/stiffness" and permeability of membranes. The significance of membrane lipid composition and membrane lipid dynamics in stress conditions has been indicated in several reviews (Kültz 2005; Park et al. 2005; Vigh et al. 2005, 2007a, b; Horváth et al. 2008, 2012; Escribá et al. 2008; Mittler et al. 2012; Filek et al. 2012; Balogh et al. 2013; Crul et al. 2013). It was suggested that stress factors can activate lipid metabolic enzymes in the direction of such changes of polar groups and fatty acid composition which can prevent cell destruction (Balogh et al. 2013). A lot of evidence was collected indicating the role of lipids in such physiological processes such as photosynthesis, signal transduction, secretion, and cytoskeletal rearrangement, organ differentiation and pollination (Wang 2002; Farmer et al. 2003; Lindsey et al. 2003; Meijer and Munnik 2003; Sperling and Heinz 2003; Welti and Wang 2004). The explanation of the changes of membrane lipids composition in stressful and physiological conditions is important for understanding the membrane and cell functions (Welti et al. 2002).

Special attention was paid to the importance of the lipid composition of chloroplast membranes. However, despite numerous studies, the details of this structure/function relationship have remained elusive. Hawke et al. (1974) and Bolton and Harwood (1978) indicated that maturity of tissues was connected with defined proportions of galactosylglycerides in chloroplast membranes especially of that reach in linolenate acid residues. Likewise, degradation of protoplast lipids in etiolated crop seedlings and light-initiated development of chloroplast thylakoid membranes stimulated synthesis of glycosylglycerides (MGDG and DGDG) and PG while PC and PE pull decreased markedly. (Harwood 1998). Pick et al. (1987) reported that sulfoquinovosyl diacylglycerol was associated with the ATP synthase and that MGDG was bound to the reaction center of PSII (Murata et al. 1990; Gombos et al. 1994).

Investigating the mutants of Arabidopsis, Millar et al. (1998) have found that plants with a high content of longchain fatty acid (18-22 carbons) were characterized by a specific modification of the chloroplast membrane structure, altered morphology (connected with the failure of flowering shoots to elongate), modified spatial pattern of siliques and altered floral phenotype.

The differences in membrane lipid composition were also linked to embryogenesis in in vitro cultures. The higher content of PE in comparison to $\mathrm{PC}$ and the presence of more unsaturated fatty acids (linolec, 18:2 and linolenic, 18:3) was observed in embryogenic membranes of wheat calli (Laggner et al. 2003). Earlier, Reidiboym-Talleux and Grenier-De March (1999) in studies of Prunus savium found that embryogenic calli were characterized by a higher content of total phospholipids compared to nonembryogenic ones and that this may be explained by the 
differences between the lipid biosynthetic pathways in both types of tissues. In the induction/blocking of embryogenesis hormones play an important role, mainly auxins. Liu et al. (1995) suggested that 2,4-D (2,4-dichlorophenoxyacetic acid-synthetic auxin), usually added to media to induce non-embryogenic calli, affected the synthesis of membrane lipids resulting in the formation of more unsaturated ones. Auxins, as negatively charged substances (derivatives of indolilo acetic acid) can be adsorbed on membranes at the places of the specific lipid composition ("domains"). The heterogeneity of the membrane structure characterized by the formation of specific centers ensures the possibility of interactions with particles of various character, present in the environment.

Taking into account the importance of the specific composition of ionic organic compounds (auxins, other anionic, i.e., gibberellins and cationic-cytokines, substances) as well as inorganic ions (e.g., calcium cations) in stimulation of physiological process (Wilson and Crawford 1974; Rochester et al. 1987a, b) the induction of ions transport alongside plants (and tissues) by external application of electric field was investigated (Verma et al. 1988; Mamta et al. 1987; Zhang et al. 1997b, 2000; Sumorek and Pietrzyk 1999; Nechitailo and Gordeev 2001; Filek et al. 2005 b). The special attention was directed to the activation of the flowering of both photo-periodic (Adamec 1989; Adamec and Krekule 1989; Adamec et al. 1989; Machácková et al. 1989) and thermo-periodic plants (Filek et al. 2002a, 2003a, 2006; Machačkova et al. 2004; Biesaga-Koscielniak et al. 2010) and to pollination process (Wędzony and Filek 1996, 1998; Mól et al. 2004).

Application of neuro-electrophysiological techniques for studying the electric properties of plant membranes allowed the description of not only differences in surface charge of the membranes of various genotypes and tissues (Kinraide et al. 1992) but also the changes caused by external chemical (Pawlikowska-Pawlega et al. 2000, 2007; Karcz and Burdach 2002; Karcz and Kurtyka 2007; Kurtyka et al. 2011) and physical factors, such as temperature (Hejnowicz et al. 1995; Filek and Kościelniak 1996, 1997; Piotrowska et al. 2000; Król et al. 2004; Karcz and Burdach 2007, Kupisz and Trebacz 2011) and light (Trębacz et al. 1989; Szarek and Trebacz 1999; Koselski et al. 2008). Electrical signals generated in plants under such conditions were classified as action potentials, similarly as was done for animal tissues. The long-distance propagation of these signals was associated with local changes of ion concentrations (mainly calcium and potassium) connected with activation of ion channels, whereas restoration of the resting potential, determined by the presence of polar and charged groups on the membrane surface (specific for each cell) was dependent on the activation of the electrogenic proton pump (Zawadzki and
Trębacz 1982, 1985; Trębacz et al. 2006). It was suggested that activation/blocking of protein channels localized in membranes was also associated with the mechanical tension via changes in unsaturation of lipid fatty acids (Allakhverdiev et al. 2001, 2010; Moreno et al. 2012).

Gas chromatography and nuclear magnetic resonance (NMR) techniques (Shiao and Shiao 1989; Kirby et al. 2011) allowed for a precise analysis of changes in the quantitative and qualitative composition of membrane lipids. In the studies of heavy metals' action it was found that their application influenced both polar and hydrophobic parts of plant membranes. High concentrations of such metals such as cadmium (Cd) (Hernandez and Cooke 1997; Quartacci et al. 2005; Nouairi et al. 2006, Filek et al. 2009, 2010), lead (Pb) (Przymusinski et al. 1991; Stefanov et al. 1993, 1995), aluminum (Al) (Lindberg et al. 1991; Papernik and Kochian 1997; Zhang et al. 1997a; Ishikawa and Wagatsuma 1998) and copper (Cu) (Quartacci et al. 2001; Ibrahim et al. 2012) induced changes in the proportions of phospholipids and galactolipids as well as in the degree of fatty acid saturation. However, this effect was strongly dependent on the composition of membrane lipids (characteristic for plant genotype) as well as on the dose of applied metals. Generally, the lipid peroxidation (an increase of fatty acid saturation) was observed due to the action of reactive oxygen species. It is assumed that excess of reactive oxygen species is generated during oxidative stress which is a consequence of the impact of environmental stress factors (Koca et al. 2007; Sharma et al. 2012).

Changes in lipid composition of plant membranes were indicated also in other types of stresses such as drought, low/high temperature and air pollution (Sikorska and Kacperska 1980; Smolenska-Sym and Kacperska 1994, 1996). Osmotic stress induced by salinity and water deficit provokes a disturbance in the relation water-ions in cells which leads to the initiation of mechanical tensions in membranes (contraction, expansion). An increased fraction of phospholipids, especially PC and an increased degree of fatty acid unsaturation was detected under such conditions (Quartacci et al. 1995; Aziz and Larher 1998; Wu et al. 2005; Toumi et al. 2008; Filek et al. 2012). However, registered modifications of the lipids composition were dependent on the tolerance of plant genotypes (genetically engineered) to osmotic stress thus changes of fatty acid saturation in the opposite direction were also found (Martins et al. 2008; Filek et al. 2012). Similarly, alterations of lipid membranes induced by low temperature were correlated with genetically modified plant resistance and/or with their acclimation to cold and frost. In most of the articles the increase of phospholipid unsaturation was established after low and frost temperature application as well as under action of air pollution (Kacperska-Palacz 1978; Yoshida 1978; Sikorska and Kacperska 1982; Jouve et al. 1993; 
Alonso et al. 1997; Harwood 1997; Routaboul et al. 2000; Campos et al. 2003; Pukacki 2004; de Oliveira et al. 2010). Such raise of a pull of unsaturated lipids associated with the formation of a more fluid membrane was suggested as one of the steps of cell protection in these stress conditions.

The presence of the hydrophobic part and hydrophilic head group in lipids gives them the ability to a specific organization in aqueous media. This structure stimulates spontaneous formation of closed structures of bi- and multi-layers (liposomes). At the hydrophobic/hydrophilic interface lipid molecules position themselves with the fatty acid residues directed toward the air and with polar groups to water forming monolayers. These structures are used to precise characterization of the modification of membranes under the influence of both chemical and physical factors. The review presents the selected physicochemical techniques that enable to describe the effects of the chemical and physical signals onto electric and structural properties of individual and mixtures of lipids.

\section{Liposomes}

Most of the plant membrane phospholipids may form in aqueous medium bi- or multi-layer liposomes (mimicking cell membranes) by sonification. Also DGDG have a tendency to build bilayers, oppositely to MGDG, which form rather hexagonal structures (Bottier et al. 2007). For formation model liposomes both individual and mixtures of lipids were used. Liposomes have drawn considerable attention as structures that may have potential application as drug carriers for target delivery (Nag and Awasthi 2013). Phospholipid liposomes exhibit negative (PG, PI, PS) or zero (PC, PE, DGDG) charge in water solution; however, to mimic the presence of proteins in membranes, cationic molecules (trimethylammonium-propane TAP) were introduced to liposomes (Ma et al. 2010). Moreover, sterols - the natural components of membranes were also used for preparation of the mixed lipid-sterol bilayers (Hua and Song-Nian 1998; Magarkar et al. 2012).

Since, in liposomes polar part of lipid molecule is exposed to water environment, thus when charged such structures can migrate in electric field. The velocity of movement of such objects (similarly as of all other charged particles) in the direction of the respective electrodes is dependent on their charge and applied electric field $\Delta E$ and is mathematically described by Smoluchowski equation:

$u=U / \Delta E=\varepsilon \varepsilon_{0} \zeta / \eta$,

where $u$ is the electrophoretic mobility equal to particle velocity $U$ per unit electric field $\Delta E, \varepsilon$ and $\varepsilon_{O}$ are dielectric constants of medium and vacuum, $\zeta$ electrokinetic potential also known as zeta potential, $\eta$ medium viscosity, $\kappa a$ particle radius normalized to the Debye length $1 / \kappa$, being a good representation of the range of electrostatic forces acting in polar media. This equation is valid for $\kappa a \gg 1$, i.e., for objects of sizes larger than Debye layer thickness.

For objects smaller than Debye length Hückel formula is valid: $u=U / \Delta E=2 \varepsilon \varepsilon_{0} \zeta / 3 \eta$. In case of objects of intermediate sizes Henry introduced correction function $f(\kappa a)$ depending on $\kappa a$ parameter $u=U / \Delta E=\left(\varepsilon \varepsilon_{0} \zeta / \eta\right) f(\kappa a)$. All these three formulas represent approximate solutions valid when particle charge and thus its potential is relatively small.

For very high $\zeta$ values, the $u=f(\zeta)$ relation can be obtained numerically only. For liposomes of defined size the Henry equation is suggested for obtaining zeta potential values as $\mathrm{f}(\kappa a)$ function can easily be obtained knowing liposome radius $a$ and medium ionic strength necessary for $\kappa$ calculation.

From measurements of electrophoretic mobility electrokinetic (zeta) potential calculated from appropriate equation can be used for obtaining the values of so called electrokinetic charge according to the formula (GouyChappmann approximation):

$\sigma=\sqrt{2 \varepsilon \varepsilon_{0} k T \sum_{i} c_{i}\left(e^{-z_{i} e \zeta / k T}-1\right)}$

where $k$ is the Boltzman constant, $T$ temperature and $e$ is the elementary charge.

Electrokinetic (zeta) potential can be measured in zetameter apparatus, where the electrophoretic mobility values are directly converted to zeta using the Henry equation. Although zeta potential is not equal to surface potential, it is often used for the characterization of electric properties of liposomes, as an analogue of resting potential of cell membrane (Kutschera et al. 2010; Honary and Zahir 2013). The electric properties of some organelles (as plastids/chloroplasts) and protoplasts, with exposed lipid layers, can also be measured (Nagata and Melchers 1978; Abe and Takeda 1988; Obi et al. 1989a, b, 1990; Gimmler et al. 1991).

Knowing the changes of electric parameters of plant cell membranes induced by the interaction with various molecules (with ionic and polar groups) some physiological properties of the membranes may be described. Based on these results, one can conclude about the density and distribution of charges localized on membrane, possible surface shielding due to adsorption of organic and inorganic polar molecules (Rabinovich-Guilatt et al. 2004; Patila et al. 2007; Huynh et al. 2009). Many physiological reactions at membranes depend on local ion concentration. Thus, information about electric properties of bilayer as a 
function of the composition of the aqueous solution and of the lipid structure may be helpful in explanation of bioprocesses.

The changes of the electrokinetic potential of plant membranes caused by various ions, which may be present inside or outside the cells, can provide information about their effect on membrane properties (Wagatsuma and Akiba 1989; Richter and Dainty 1990; Gringon and Sentenac 1991; Marschner 1995; Franco et al. 2002). The response of plant cell membranes to $\mathrm{H}^{+}, \mathrm{Na}^{+}, \mathrm{Ni}^{2+}, \mathrm{Ca}^{2+}$, $\mathrm{Al}^{3+}, \mathrm{La}^{3+}, \mathrm{SeO}_{4}{ }^{2-}$ at toxic concentrations were analyzed in detail (McLaughlin and Whitaker 1988; Suhayda et al. 1990; Kinraide 1994, 1998a, 2003; Kinraide et al. 1998; Zhang et al. 2001). It was indicated that electric potential of model membranes was dependent on both the amount and valency of ionic groups in adsorbed molecules, $(\mathrm{Ru}-$ dolphi-Skórska et al. 2014b), and their dimensions (Filek et al. 1982).

The biological interpretation of electric properties of lipid bilayers (surface charge, electric potential) was enriched by measurements of ion adsorption (Yermiyahu et al. 1997a, b) and ion distribution at cell membranes (Kirchner 1996). Experimental results of electrokinetic potentials and ion adsorption allowed us to use theoretical models for the description of the possibility of ion binding at various sites ("domains") of cell membranes. These models were subsequently verified by experiments leading to an estimation of the interaction of ions with various surface groups (Kinraide et al. 1998). It was found that theoretically calculated values of the electric potential of mixed lipid layers correlated very well with the published zeta potentials of native protoplasts of various plants. For protoplast membranes, isolated from root system, it was shown that adsorption of inorganic ions on the surface of increased negative charge density correlated with ion charge and size. This information can be used to predict the possibility of growth and development of some genotypes (characteristic electric potential of root membranes) in a particular environment (of characteristic ion composition). Comparison of electrokinetic potential with resting potential measured using microelectrodes (surface potential of membranes) proved the very good agreement between results obtained by both techniques (Shomer et al. 2003).

Liposomes, prepared from individual lipids were also used in studies of interactions with organic substances such as peptides and antibodies (McLaughlin and Whitaker 1988; Beschiaschvili and Seelig 1992), hormones and polar organic substances (Filek et al. 2002b; Gzyl-Malcher et al. 2007; Pawlikowska-Pawlega et al. 2014). It was indicated that hormones of ionic character (as negatively charged auxins and gibberellins or positively charged cytokines) as well as molecules with polar groups (toxin-zearalenone) may modify the electric properties of liposomes composed of both negatively charged phospholipids (PG) and zwitterionic PC and PE. On the basis of changes of electrokinetic potential, the possibility of their adsorption on membranes containing these lipids was suggested. Detailed studies of lipids with defined amounts of saturated and/or unsaturated fatty acids allowed us to discuss the possibility of incorporation of some substances of more hydrophobic character (sterols, tocopherols) into lipid layer. Biological interpretation of electric properties of lipid membranes may be useful in explanation of some physiological and stress induced processes.

In Table 3 some examples of zeta potential data of liposomes and organelles isolated from plant cells are collected.

For chloroplasts, isolated from plants, it was found that after application of hormones electrokinetic potential of their membranes was changed in the same direction as that of liposomes, prepared from lipids extracted from chloroplasts (Filek et al. 2007). These dependencies were observed independently on tissue (vegetative and generative apexes of rape) from which lipids and chloroplasts were extracted. It was shown that gibberellic acid-hormone important for stimulation of generative development of winter plants-had stronger influence on physicochemical properties of membranes of apexes of vegetative plants, whereas, auxins-hormones which usually block the generative development of apexes - showed relatively weak action.

Some differences in values of electrokinetic potential obtained for model liposomes and native membranes were assigned to the presence of proteins containing charged groups. Comparison of electric charges calculated from electrokinetic potential of protoplasts and liposomes (prepared from protoplast' lipids) allowed to separate the effects associated only with the presence of lipids originating from proteins (Filek et al. 2002b).

\section{Monolayers}

Lipid monolayers formed spontaneously at the water-air interface provide a model for studying the two-dimensional structure of this system (McConnell 1991; Knobler and Desai 1992; Möhwald 1993), to elucidate the interactions with polar substances (adsorbed from water solution-to mimic the polar side of cell membrane), as well as the effect of non-polar molecules incorporated into layer. Lipid monolayers are prepared using the Langmuir technique. In this technique, the dependence of surface pressure $(\pi)$ on the layer compression degree (expressed by the value of the area accessible for dispersed molecule $A$ ) is measured to 
Table 3 Zeta potential $(\mathrm{mV})$ of native plant membranes (protoplasts and organelles) and of liposomes, prepared from lipid membranes

\begin{tabular}{|c|c|c|c|c|c|}
\hline Organelles & $\begin{array}{l}\text { Zeta/surface } \\
\text { potential } \\
(\mathrm{mV})\end{array}$ & References & Liposomes & $\begin{array}{l}\text { Zeta/surface } \\
\text { potential } \\
(\mathrm{mV})\end{array}$ & References \\
\hline Protoplast & -17 to -50 & $\begin{array}{l}\text { Nagata and Melchers 1978; Gibrat } \\
\text { et al. 1985; Oka et al. 1988; Abe and } \\
\text { Takeda 1988; Obi et al. 1989a, b, } \\
\text { 1990; Pilet et al. 1985; Gimmler } \\
\text { et al.1991; Zhang et al. 2001; Filek } \\
\text { et al. 2002b, Kinraide 2003; Ahn } \\
\text { et al. 2004; Wang et al. 2008; } \\
\text { Kinraide and Wang 2010; Li et al. } \\
\text { 2014 }\end{array}$ & $\begin{array}{l}\text { Mixture of } \\
\text { phospholipids }\end{array}$ & -20 to -40 & $\begin{array}{l}\text { Bérczi et al. 1984; Møller et al. } \\
\text { 1984b; Gibrat et al. 1985; Körner } \\
\text { et al. 1985; Bérczi and Møller 1993 } \\
\text { Yermiyahu et al. 1994, 1997a, b; } \\
\text { Liu et al. 2001; Fatouros et al. 2001 } \\
\text { Filek et al. 2002a, 2002b; } \\
\text { Mozuraityte et al. } 2006\end{array}$ \\
\hline Chloroplast & -14 to -36 & $\begin{array}{l}\text { Chow and Barber 1980; Conjeaud and } \\
\text { Mathis 1986; Doltchinkova and } \\
\text { Lambreva 2002; Dahlin 2003; Filek } \\
\text { et al. 2007, } 2010\end{array}$ & $\mathrm{PC}$ and $\mathrm{PE}$ & 0 to -10 & $\begin{array}{l}\text { Plank et al. 1985; Klein et al. 1987; } \\
\text { Makino et al. 1991; Petelska and } \\
\text { Figaszewski 2000; Tseng et al. } \\
\text { 2007; Mady and Darwish 2010; } \\
\text { Carter et al. 2014; Magarkar et al. } \\
\text { 2014; Rudolphi-Skórska et al. } \\
\text { 2014b }\end{array}$ \\
\hline \multirow[t]{2}{*}{ Mitochondria } & $-33 \mathrm{mV}$ & Møller et al. 1984a & PG and PA & $\begin{array}{r}-20 \text { to } \\
-100\end{array}$ & $\begin{array}{l}\text { Liu et al. 2001; Rudolphi-Skórska } \\
\text { et al. } 2014 \mathrm{~b}\end{array}$ \\
\hline & & & DGDG & -15 to -40 & $\begin{array}{l}\text { Christianssons et al. 1985; Chu et al. } \\
2009\end{array}$ \\
\hline
\end{tabular}

Different $\mathrm{mV}$ ranges are connected with the presence of various polar group of lipids in bilayers of natural and model membranes as well as with ionic concentration of water phase

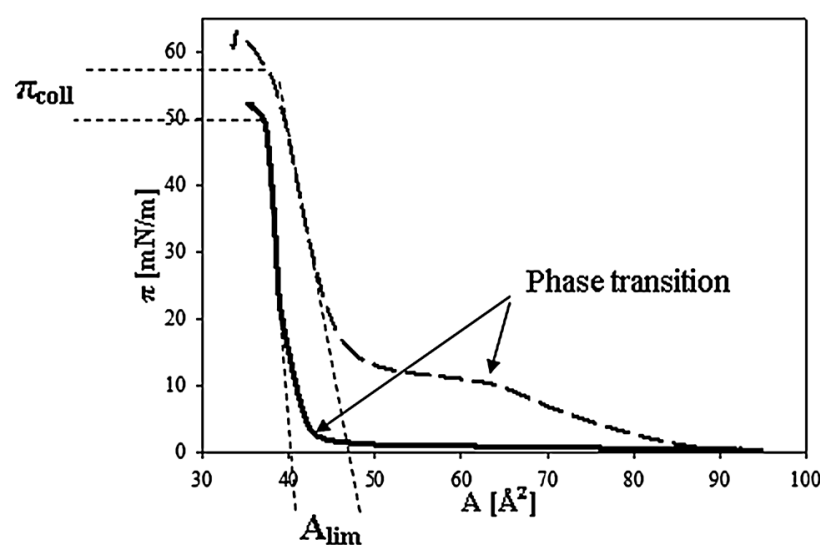

Fig. 1 Example of $\pi$-A isotherms for phospholipids' monolayers: solid line-DPPA (1,2- dipalmitoyl-sn-glycero-3-phosphate), dash line-DPPC 1,2-dipalmitoyl-sn-glycero- 3-phosphocholine

obtain so called surface pressure isotherm. Surface pressure is defined as the difference of surface tensions of the airwater interface $\left(\gamma_{0}\right)$ minus that of the interface covered by the monolayer $(\gamma)$. For some systems compression of the monolayer causes a series of two-dimensional phase transitions (Andelman et al. 1994). At some two-dimensional density of molecules (at defined compression degree), the hydrophobic parts of the molecules come into, but a layer remains disordered and fluid. Further compression can lead to layer transition to more condensed state, marked by a plateau in the isotherm or different slope of the isotherm. At further increase of molecular density highly ordered state, similar to that found in liquid crystals is formed (Figure 1).

At some stage corresponding to the highest molecular packing layer cannot be further compressed without destabilizing its two-dimensional structure (Gopal and Lee 2001). The surface pressure in such condition is defined as collapse pressure $\left(\pi_{\text {coll }}\right)$ is equivalent to the minimum surface tension of a monolayer. For fully compressed monolayers, the area per molecule ( $A_{\text {lim }}$, limiting area) is the smallest and characteristic for lipids building the layer. These two parameters, i.e., collapse pressure and limiting area can be easily determined being very important parameters characterizing a layer interacting with aqueous subphase of defined composition. Kundu et al. (2005) described two characteristic types of layer collapse: (1) when abrupt decrease of surface pressure appears after reaching its maximal value-so-called constant area collapse or (2) when the pressure remains almost constant despite the further compression-so-called constant pressure collapse.

The surface parameters $\left(\pi_{\text {coll }}\right.$ and $\left.A_{\text {lim }}\right)$ of Langmuir monolayers are used to detect subtle changes of mechanical properties related to the presence of various polar head groups in lipids and varying degrees of saturation of fatty acid residues. Their values allow to conclude about formation of "domains" which may interact with water soluble substances (Vollhardt 1993; Hu and Granek 1996) as well 
as to speculate about monolayer thicknesses (Saint-Jalmes and Gallet 1998). Application of Brewster angle microscopy or scanning probe microscopy makes possible the monitoring of the microdomains at a layer surface resulting from the interactions with molecules adsorbed from a subphase (Dynarowicz-Łątka et al. 2002; Miñones et al. 2002; Gzyl-Malcher et al. 2011; Sakamoto et al. 2013).

Stearic acid (SA), as a component of lipids in the membranes of plants and animals (Greń et al. 2012), was often used as reference substance for the study of the structural properties using Langmuir monolayers as model system. The presence of the polar carboxyl group and a long saturated hydrocarbon chain of the acid molecule allowed a spontaneous organization at the water/air interface (of hydrophilic/hydrophobic character).

Studying stearic acid monolayers, Kundu and Langevin (2008) showed the changes in the values of collapse pressure in the presence of both: monovalent $\left(\mathrm{Na}^{+}\right)$and divalent $\left(\mathrm{Mg}^{2+}, \mathrm{Ca}^{2+}, \mathrm{Ba}^{2+}, \mathrm{Zn}^{2+}\right.$, and $\left.\mathrm{Cd}^{2+}\right)$ ions. The authors found that the degree of dissociation of the carboxyl group ( $\mathrm{pH}$ dependent) affects isotherm shape and $\pi_{\text {coll }}$ value. This process was observed in the presence of both: mono- and bi-valent ions, being also dependent on the size of particular cation present in aqueous solution. Yazdanian et al. (1990) showed that under $\mathrm{pH}$ conditions in the range 5.5-6.0, i.e., as frequently occur in plant cells, appear the interaction of ions with monolayers.

The impact of ions on the "stability" of the monolayers was also studied. Avila et al. (1999) analyzed the change (decrease) of the $A$ value at the set $\pi$ levels. They found that this parameter is also dependent on the $\mathrm{pH}$ of the aqueous medium. The measurements of surface potential of Langmuir monolayers have shown that more stable layers are formed in the presence of cations (Yazdanian et al. 1990). This was explained as due to the compensation of negative charge of fatty acid monolayers by cations. Effect of trivalent ions so far has not been intensively studied. Only for the so-called rare elements, Silva et al. (1998) showed that in the presence of europium (Eu) and terbium (Tb) ions "loosening" of the surface structure occurs, while the opposite effect was observed after introduction of yttrium (Y) ions to the aqueous phase (Zotova et al. 1998). The differences between the impact of these ions on fatty acid monolayers can be related to sizes of ions and their sorption capacity.

Another important structural feature of the monolayers, which can be determined from $\pi-A$ dependencies is socalled "elasticity". Modification of the Langmuir technique by the introduction of dynamic oscillation function enabled He et al. (2002) to determine "dynamic elasticity" of stearic acid monolayer on water and on aqueous solutions containing bi- $\left(\mathrm{CdCl}_{2}\right)$ and tri-valent $\left(\mathrm{TbCl}_{3}\right)$ ions. They showed differences in monolayers" "elasticity" dependent on the presence of both types of ions. In the presence of $\mathrm{Cd}$ ions elasticity of stearic acid layer was discontinuous function of molecular packing while in the presence of the $\mathrm{Tb}$ ions such "discontinuity" did not exist.

Abousalham et al. (2000) compared the properties of the monolayers prepared from stearic acid (saturated) with those obtained for the unsaturated fatty acids (oleic, linoleic, ricinoleic acids) and their oxidized forms: $13(S)$-hydroperoxyoctadeca-9Z, 11E-dienoic (13-HPODE) and 13 $(S)$-hydroxyoctadeca-9Z, 11 Edienoic (13 Hode) acids. They showed that the monolayers formed from acids containing unsaturated bonds and from oxidized fatty acids are more expanded. Measurements of surface potentials of the monolayers (using vibrating sensor electrode) allowed to conclude that orientation of molecules in layers formed from oxidized fatty acids was changed. With increasing compression degree molecules of these oxidized fatty acids underwent spontaneous desorption from monolayer to the aqueous subphase. This is an important observation that can be used to elucidate the mechanisms of physiological processes associated with stress, particularly with oxidative stress associated with oxidation by reactive oxygen species.

The fatty acids were also used as model substances in the preparation of two-component monolayers, mainly with cholesterol (an important component of cell membranes). The presence of $\mathrm{OH}$ group in the ring structure of cholesterol allows spontaneous organization of mixtures of this compound with long-chain fatty acids. Sparr et al. (1999) showed that, depending on the concentration of cholesterol in mixture with saturated fatty acid (palmitic acid, 16:0) either homogeneous monolayer with a uniform surface structure (at low cholesterol concentration) or heterogeneous ones (at higher ratios of cholesterol:fatty acid), rougher, comprising local folding, are formed. This effect can be explained by the presence in the native membranes "domains" of different sizes and shapes favorable specific adsorption of organic and inorganic substances from the aqueous medium.

\section{Studies of monolayers of membrane lipids}

\section{Studies of phospholipid monolayers}

The simplest phospholipid, in terms of chemical structure is a phosphatidic acid containing a negatively charged, phosphoric acid residue. Although, as shown previously (Table 1) in cell membranes it is present only in relatively small concentrations, it plays an important role in physiological processes as a significant signal substance (Testerink and Munnik 2005). Studies of phosphatidic acid monolayers, containing a saturated (myristic, 14:0) fatty acid as hydrophobic part (1,2-dimyristoyl-sn-glycero-3phosphate, DMPA), provided information on the changes 
of monolayer "stiffness" depending on the ordering of the acyl chains. Schalke et al. (2000) suggest that the presence of saturated fatty acid residues causes a bent of hydrophilic part of the lipid (to "adapt" to the shrinking area available for molecules) which results in the formation of structures of a higher density of negative charge. This indicates that the increase in saturation of fatty acids in lipids of native membranes not only reduces the "permeability" of their hydrophobic part but also favors the formation surface "domains" exhibiting higher density of negative charge, which in turn may affect the possibility of adsorption of the compounds from cytosol (or inter-cellular space).

Effect of organic and inorganic ions on the structural properties of phosphatidic acid monolayers was examined inter alia by Vaknin et al. 2003; Faraudo and Travesset $2007 \mathrm{a}$, b. The presence of polyamines, polycationic compounds responsible for the developmental processes of plants and their resistance to stress conditions, significantly modify both the surface pressure isotherms of monolayers and the electrokinetic potential of liposomes (RudolphiSkórska et al. 2014b). It was found that putrescine (polyamine of two positive charges) had a similar effect on physico-chemical parameters of the monolayers to that which was recorded for calcium ions. This may indicate that for modification of the structural and electrical properties of the cell membrane more important is the electric charge than the chemical structure of the adsorbed compound (organic and non-organic counter-ion).

The influence of calcium ions on the monolayers' structure was also tested in systems formed from other than phosphatidic acid lipids, containing more complex polar part with the exposed negative charge. Garidel et al. (2000) showed that these ions may partially penetrate phosphatidylglycerol (PG) monolayers containing saturated fatty acid residues DMPG (1,2-dimyristoyl-sn-glycero-3phospho-1-glycerol), which polar region, compared to monolayers of phosphatidic acid, is significantly larger. It was found that while the $\mathrm{Ca}^{2+}$ ions induce condensation of PG monolayer other bivalent ions $\left(\mathrm{Mg}^{2+}\right.$ and $\left.\mathrm{Sr}^{2+}\right)$ act inversely. These different effects can be explained by two counter-acting processes: for calcium-by formation of ionic bonds with negative groups of phosphatidylglycerol (thus promoting formation of a more compact structure), while for $\mathrm{Mg}^{2+}$ and $\mathrm{Sr}^{2+}$ - by ionization of lipid polar groups (leading to the layer expansion) (Garidel and Blume 2005). Infrared reflection absorption spectroscopy (IRAS), $\mathrm{X}$-ray diffraction and reflectivity measurements confirmed that the ordering degree (condensation) of DPPG monolayers (1,2-dipalmitoyl-sn-glycero-3-phospho-glycerol) is dependent on the chemical nature of the interacting ion (Maltseva et al. 2006). In simultaneous presence of monoand di-valent cations competition between layer condensing action of $\mathrm{Ca}^{2+}$ cations, and a condensation preventing influence of $\mathrm{Na}^{+}$may lead to formation of "domains" of irregular shape and various sizes (Grigoriev et al. 2003). It has been postulated that the ionization of polar groups of PG caused an increase of hydration degree, which may result in local "deeper dipping" of the layer in the aqueous phase (Miñones et al. 2003). Experiments in which protein components (photosystem PSI) were introduced into PG monolayers (model of chloroplasts membranes) allowed to conclude about the changes in photosynthetic activity in the presence of cation excess. Wu et al. (2005) demonstrated that calcium ions modify the interaction between PSI and PG, mainly by neutralizing the phosphate group of PG, which resulted in a reorganization of the molecules in the PSI complex. Testing temperature dependence of the structural properties of DPPG monolayers showed the probability of formation of the lipid aggregates at lower temperatures, close to phase transition temperature (Vollhardt et al. 2000). This observation may be important for understanding the mechanisms of membrane changes in physiological processes occurring at low temperatures (stress, vernalization).

By studying mixed monolayers, formed from lipids containing the same polar groups differing in saturation degree of fatty acid residues Sanchez and Badia (2003) characterized the changes in the structure of the dialkylphosphatidylcholines (DPPC/DLPC; phosphatidylcholines with palmitic-16:0 and lauric 12:0 acids) mixed monolayers as a function of the ratio of the lipids. The authors showed that in such systems "domains" rich in lipid with longer fatty acid residues (DPPC) "floating" in the matrix of shorter lipid (DLPC arise) are formed. The existence of domains was also confirmed in the AFM (atomic force microscopy) images for mixtures of phosphatidylcholines with saturated (16:0) and unsaturated (18:1) acids (DPPC/DOPC) (Jurak and Chibowski 2010). The results of these studies lead to the conclusion that the presence of acids of fewer $\mathrm{CH}_{2}$ groups and higher unsaturation degree promotes the formation of the matrix for "domains" containing lipids of longer and saturated hydrocarbon chains. In mixed monolayers composed of the lipids of the same composition of hydrophobic part (16:0) and different polar groups (PC and PG) Saad et al. (2009) showed that mixed layers with greater fraction of DPPG exhibit higher elasticity. This physico-chemical property may be important in explaining physiological role of changes in lipid composition of native membranes during adaptation of cells to the action of low/high temperatures.

The effect of $\alpha$-tocopherol (which increased concentration in natural membranes) is related to the adaptation of cells to stress conditions (Munné-Bosch et al. 1999) introduced to model lipid layers was examined inter alia by Jurak and Minones-Conde (2013) and Rudolphi-Skórska et al. (2014a). It has been shown (Jurak and Minones- 
Conde 2013) that $\boldsymbol{\alpha}$-tocopherol causes a destabilization of the layers of lipids containing saturated fatty acids (DPPC) by decreasing the ordering of the acyl chains, whereas it increases the stability of monolayers composed of unsaturated lipids (POPC/DOPC). These observations may help to clarify the cause-and-effect between changes in lipid unsaturation and tocopherol synthesis in cells exposed to stress factors.

Introduction of TAP — synthetic lipid with cationic polar group, to the phospholipid layer was a model for reasoning about the properties of monolayers containing the positively charged protein structures (model of natural membrane). In Gzyl-Malcher et al. (2011) studies it was found that the positive net charge of mixed DPPC/DTAP layers can be neutralized by introducing inorganic anions $\left(\mathrm{SeO}_{4}{ }^{2-}\right)$ to water solution, whereas organic anions (hormone-auxin) may penetrate the lipid monolayer causing its expansion/fluidization. Inorganic ions and charged hormones simultaneously present in aqueous phase interact in competitive way with oppositely charged polar groups of mixed layers formed from negatively charged DMPS (1,2dimyristoyl-sn-glycero-3-phospho-L-serine) and DPTAP (Gzyl-Malcher et al. 2009).

Studies using Langmuir technique were performed also for mixtures of phospholipids extracted from the plants for detecting the changes of structural properties of membranes associated with the differentiation (embryogenesis) (Filek et al. 2003a, b, 2005a; Gzyl et al. 2004; Gzyl-Malcher et al. 2007). Lipids obtained from non-embryogenic calli formed more "condensed" monolayers than that from embryogenic calli. In the presence of hormones, the larger changes of monolayer properties were detected for lipids of non-embrogenic in comparison to that of embryogenic calli. This may suggest that the presence of hormones in media of non-embryogenic calli is necessary to induce changes in membrane structure needed for differentiation processes in the direction of embryogenesis.

\section{Studies of glycolipid monolayers}

In comparison to experiments carried out for model phospholipid systems, physicochemical properties of layers of galactolipids, (compounds typical for plant cell membranes) were tested to a lesser extent. Glycolipids: digalactosyldiacylglycerol (DGDG) and the mono-galactosyldiacylglycerol (MGDG) constitute a major class (approx. $75 \%$ ) of lipids of chloroplasts membranes (Dormann and Benning 2002; Hincha 2003; Bruno et al. 2005). Compared to the layers formed from individual galactolipids, an equimolar mixture of MGDG and DGDG exhibits different physico-chemical properties, indicating interactions between the polar groups at the water/air interface. Studies of Bottier et al. (2007) using Raman and
Fourier Transform Infrared (FTIR) spectroscopies confirmed the existence of such interactions, as evidenced by higher ordering of the acyl chains in the mixture, than in layers formed from the individual components. The work of Gzyl-Malcher et al. (2008), based on the analysis of structural parameters of monolayers formed from galactolipids extracted from callus cells (obtained from a variety of plant tissues) demonstrated that layers of galactolipids extracted from inflorescences are more expanded and less stable than those formed from galactolipids extracted from immature embryos. Since the calli derived from immature embryos exhibit greater regenerative abilities than those obtained from the inflorescences, the differences in the structure of the membranes of the two tissues may be important in describing the mechanism of plant regeneration.

The balance between the amount of DGDG and MGDG is essential for the functioning of proteins that form antenna complexes of photosystems in chloroplasts (Pali et al. 2003). As shown by Dynarowicz-Łątka et al. (2005), the presence of glycolipids in mixed monolayers containing also phospholipids plays an important role in the organization of the monolayer. Depending on the amount of the sugar groups a partial segregation of the monolayer arises.

This may explain the possibility of the specific inclusion of photosystem complexes PSII and PSI by the lipid membranes of chloroplasts.

The role of tocopherol in protection of chloroplast membrane against reactive oxygen species generated during photosynthesis and under environmental stress conditions was studied by Rudolphi-Skórska et al. (2014b). It was found that the presence of tocopherol in ozonized monolayer of MGDG or DGDG partially inhibits lipid oxidation by reducing the amount of lipid undergoing oxidation. The protective action of tocopherol was greater for lipid with single sugar group.

The physicochemical properties of galactolipid layers were also tested in terms of interaction with metal ions. In view of the importance of the stress induced by cadmium ions for physiological processes occurring in chloroplasts the changes of structural parameters of mixed monolayers of MGDG and DGDG caused by the interaction with the metal ions were determined. Gzyl-Malcher et al. (2008) showed that cadmium ions to a greater extent influence structural properties of glycolipid containing one sugar group. Introduction of tocopherol to MGDG/DGDG mixtures affected the interaction of $\mathrm{Cd}$ ions with monolayers, independently of proportions between galactolipid species (Gzyl-Malcher et al. 2010). This observation can be used to conclude about the physiological modification of the glycolipid composition in chloroplast membranes in processes of plant adaptation to the stress caused by heavy metals. 


\section{Conclusion}

Examples of use of the results of the measurements of physicochemical properties of lipids for interpretation of the structural and functional changes in the native membranes were presented. The continuation of this type of research may contribute to the detailed description of the mechanism of physiological reactions occurring under stress and during the course of developmental processes in plants.

Author contribution statement Study conception and design: Rudolphi-Skórska E., Sieprawska A.; acquisition of data: Rudolphi-Skórska E.; analysis and interpretation of data: none; drafting of manuscript: Rudolphi-Skórska E., Sieprawska A.; critical revision: Rudolphi-Skórska E., Sieprawska A. Author's percent contribution: RudolphiSkórska E.—60 \%; Sieprawska A.—40\%

Open Access This article is distributed under the terms of the Creative Commons Attribution 4.0 International License (http://crea tivecommons.org/licenses/by/4.0/), which permits unrestricted use, distribution, and reproduction in any medium, provided you give appropriate credit to the original author(s) and the source, provide a link to the Creative Commons license, and indicate if changes were made.

\section{References}

Abe S, Takeda J (1988) Effects of $\mathrm{La}^{3+}$ on surface charges, dielectrophoresis, and electrofusion of barley protoplast. Plant Physiol 87:389-394

Abousalham A, Fotiadu F, Buono G, Verger R (2000) Surface properties of unsaturated non-oxidized and oxidized free fatty acids spread as monomolecular films at an argon: water interface. Chem Phys Lipids 104:93-99

Adamec L (1989) The comparison between membrane and transorgan electric potentials in Chenopodium rubrum: the methods. Biol Plant 31:327-335

Adamec L, Krekule J (1989) Changes in membrane potential in Chenopodium rubrum during the course of photoperiodic flower induction. Biol Plant 31:336-343

Adamec L, Macháčková I, Krekule J, Nováková M (1989) Electric current inhibits flowering in the short-day plant Chenopodium rubrum L. J Plant Physiol 134:43-46

Ahn SJ, Rengel Z, Matsumoto H (2004) Aluminum-induced plasma membrane surface potential and $\mathrm{H}+$-ATPase activity in nearisogenic wheat lines differing in tolerance to aluminum. New Phytol 162:71-79

Allakhverdiev SI, Kinoshita M, Inaba M, Suzuki I, Murata N (2001) Unsaturated fatty acids in membrane lipids protect the photosynthetic machinery against salt induced damage in Synechococcus. Plant Physiol 125:1842-1853

Allakhverdiev SI, Los DA, Murata N (2010) Regulatory roles in photosynthesis of unsaturated fatty acids in membrane lipids. In: Wada H, Murata N (eds) Lipids in photosynthesis: essential and regulatory functions. Advances in photosynthesis and respiration, vol 30. Springer, Dordrecht, pp 373-388

Allen CF, Good P, Davis HF, Fowler SD (1964) Plant and chloroplast lipids I. Separation and composition of major spinach lipids. Biochem Biophys Res Commun 15:424-430
Alonso C, Suidan MT, Sorial GA, Smith FL, Biswas P, Smith PJ, Brenner RC (1997) Gas treatment in trickle-bed biofilters: biomass, how much is enough? Biotechnol Bioeng 54:583-594

Andelman D, Brochard F, Knobler C, Rondelez F (1994) Structures and phase transitions in Langmuir monolayers. Springer, New York, pp 559-602

Avila LVN, Saraiva SM, Oliveira JF (1999) Stability and collapse of monolayers of stearic acid and the effect of electrolytes in the subphase. Colloids Surf A 154:209-217

Aziz A, Larher F (1998) Osmotic stress induced changes in lipid composition and peroxidation in leaf discs of Brassica napus $\mathrm{L}$. J Plant Physiol 153:754-762

Balogh G, Péter M, Glatz A, Gombos I, Török Z, Horváth I, Harwood JL, Vígh L (2013) Key role of lipids in heat stress management. FEBS Lett 587:1970-1980

Bérczi A, Møller IM (1993) Surface charge density estimation by 9-aminoacridine fluorescence titration: improvements and limitations. Eur Biophys J 22:177-183

Bérczi A, Møller IM, Lundborg T, Kylin A (1984) The surface charge density of wheat root membranes. Physiol Plant 61:535-540

Beschiaschvili G, Seelig J (1992) Peptide binding to lipid bilayers. Nonclassical hydrophobic effect and membrane-induced $\mathrm{pK}$ shifts. Biochemistry 31:10044-10053

Biesaga-Kościelniak J, Kościelniak J, Filek M, Marcińska I, Krekule J, Machaćkova I, Kubon M (2010) The effect of plant growth regulators and their interaction with electric current on winter wheat development. Acta Physiol Plant 32:987-995

Bolton P, Harwood JL (1978) Lipid metabolism in green leaves of developing monocotyledons. Planta 139:267-272

Borochov A, Walker MA, Kendall EJ, Pauls KP, McKersie BD (1987) Effect of a freeze-thaw cycle on properties of microsomal membranes from wheat. Plant Physiol 84:131-134

Bottier C, Géan J, Artzner F, Desbat B, Pézolet M, Renault A, Marion D, Vié V (2007) Galactosyl head group interactions control the molecular packing of wheat lipids in Langmuir films and in hydrated liquid-crystalline mesophases. Biochim Biophys Acta 1768:1526-1540

Brown FLH (2011) Continuum simulations of biomembrane dynamics and the importance of hydrodynamic effects. Q Rev Biophys 44:391-432

Browse J, McCourt PJ, Somerville CR (1986) Fatty acid composition of leaf lipids determined after combined digestion and fatty acid methyl ester formation from fresh tissue. Anal Biochem 152:141-145

Bruno A, Rossi C, Marcolongo G, Di Lena A, Venzo A, Berrie CP, Corda D (2005) Selective in vivo anti-inflammatory action of the galactolipid monogalactosyldiacylglycerol. Eur J Pharmacol 524:159-168

Cacho M, Peláez R, Corchete P (2012) Lipid composition of Silybum marianum cell cultures treated with methyl jasmonate. Biol Plant $56: 221-226$

Campos PS, Quartin V, Ramalho JC, Nunes MA (2003) Electrolyte leakage and lipid degradation account for cold sensitivity in leaves of Coffea sp plants. J Plant Physiol 160:283-292

Carter KA, Shao S, Hoopes MI, Luo D, Ahsan B, Grigoryants VM, Song W, Huang H, Zhang G, Pandey RK, Geng J, Pfeifer BA, Scholes CP, Ortega J, Karttunen M, Lovell JF (2014) Porphyrinphospholipid liposomes permeabilized ny near-infrared light. Nature Commun 5:3546. doi:10.1038/ncomms4546

Chapman D (1975) Phase transition and fluidity characteristics of lipids and cell membranes. Q Rev Biophys 8:185-235

Chapman DJ, de Felice J, Barber J (1986) Polar lipid composition of chloroplast thylakoids isolated from leaves grown under different lighting conditions. Photosynth Res 8:257-265

Chow WS, Barber J (1980) 9-Aminoacridine fluorescence changes as a measure of surface charge density of the thylakoid membrane. Biochim Biophys Acta 589:346-352 
Christianssons A, Eriksson GLE, Westman J, Demell R, Wieslander A (1985) Involvement of surface potential in regulation of polar membrane lipids in Acholeplasma laidlawii. J Biol Chem 260:3984-3990

Chu BS, Rich GT, Ridout MJ, Faulks RM, Wickham MSJ, Wilde PJ (2009) Modulating pancreatic lipase activity with galactolipids: effects of emulsion interfacial composition. Langmuir 25:9352-9360

Conjeaud H, Mathis P (1986) Electron transfer in the photosynthetic membrane. Influence of $\mathrm{pH}$ and surface potential on the P-680 reduction kinetics. Biophys J 49:1215-1221

Crul T, Toth N, Piotto S, Literati-Nagy P, Tory K, Haldimann P, Kalmar B, Greensmith L, Torok Z, Balogh G, Gombos I, Campana F, Concilio S, Gallyas F, Nagy G, Berente Z, Gungor B, Peter M, Glatz A, Hunya A, Literati-Nagy Z, Vigh LJ, Hoogstra-Berends F, Heeres A, Kuipers I, Loen L, Seerden J, Zhang D, Meijering RAM, Henning RH, Brundel BJJM, Kampinga HH, Koranyi L, Szilvassy Z, Mandl J, Sumegi B, Febbraio MA, Horvath I, Hooper PL, Vigh L (2013) Hydroximic acid derivatives: pleiotropic Hsp co-inducers restoring homeostasis and robustness. Curr Pharm Des 19:309-346

Dahlin C (2003) Surface charge densities and membrane fluidities in thylakoids with different degrees of thylakoid appression after Norflurazon treatment. Photosynthetica 41:635-639

de Oliveira LMN, de M. Sobreira AC, de P. Monteiro F, de Melo DF (2010) Chill-induced changes in fatty acid composition of tonoplast vesicles from hypocotyls of Vigna unguiculata (L.) Walp. Braz J Plant Physiol 22:69-72

Doltchinkova V, Lambreva M (2002) Effect of pH on the electrokinetic and light scattering properties of pea thylakoids in the presence of phytohemagglutinin. Bulg J Plant Physiol 28:45-58

Dörmann P, Benning C (2002) Galactolipids rule in seed plants. Trends Plant Sci 7:112-118

Dorne AJ, Joyard J, Douce R (1990) Do thylakoids really contain phosphatidylcholine? Proc Natl Acad Sci USA 87:71-74

Douce R (1985) Mitochondria in higher plants: structure, function and biogenesis. Academic, Orlando, pp 50-59

Dynarowicz-Łatka P, Rosilio V, Boullanger P, Fontaine P, Goldmann M, Baszkin A (2005) Influence of a neoglycolipid and Its PEOlipid moiety on the organization of phospholipid monolayers. Langmuir 21:11941-11948

Dynarowicz-Łątka P, Seoane R, Miñones J Jr, Velo M, Miñones J (2002) Study of penetration of amphotericin B into cholesterol or ergosterol containing dipalmitoyl phosphatidylcholine Langmuir monolayers. Colloids Surf B 27:249-263

Escribá PV, González-Ros JM, Goñi FM, Kinnunen PKJ, Vigh L, Sánchez-Magraner L, Fernández AM, Busquets X, Horváth I, Barceló-Coblijn G (2008) Membranes: a meeting point for lipids, proteins and therapies. J Cell Mol Med 12:829-875

Evans DE, Sang JP, Cominos X, Rothnie NE, Knox RB (1990) A study of phospholipids and galactolipids in pollen of two lines of Brassica napus L. (Rapeseed) with different ratios of linoleic to linolenic acid. Plant Physiol 92:418-424

Faraudo J, Travesset A (2007a) Electrostatics of phosphatidic acid monolayers: insights from computer simulations. Colloids Surf A 300:287-292

Faraudo J, Travesset A (2007b) Phosphatidic acid domains in membranes: effect of divalent counterions. Biophys J 92:2806-2818

Farmer EE, Alméras E, Krishnamurthy V (2003) Jasmonates and related oxylipins in plant responses to pathogenesis and herbivory. Curr Opin Plant Biol 6:372-378

Fatouros D, Gortzi O, Klepetsanis P, Antimisiaris SG, Stuart MCA, Brisson A, Ioannou PV (2001) Preparation and properties of arsenolipid containing liposomes. Chem Phys Lipids 109:75-89

Filek M, Kościelniak J (1996) The effect of chilling maize shoots and roots on the electric potential, composition of fatty acids and the
ATPase activity in the non-chilled organs of seedlings. J Agro Crop Sci Zeitschr fur Acker und Pflanzenbau 177:261-267

Filek M, Kościelniak J (1997) The effect of wounding the roots by high temperature on the respiration rate of the shoot and propagation of electric signal in horse bean seedlings (Vicia faba L minor). Plant Sci 123:39-46

Filek M, Paluch M, Waligóra B (1982) Electrical-properties of the monolayers of para-phenol derivatives. J Colloid Interface Sci 89:166-169

Filek M, Biesaga-Kościelniak J, Marcińska I, Krekule J, Machačkova I (2002a) Direct electric current partly replaces the chilling effect in vernalisation of winter wheat. J Plant Physiol 159:795-797

Filek M, Zembala M, Szechyńska-Hebda M (2002b) The influence of phytohormones on zeta potential and electrokinetic charges of winter wheat cells. Zeitschr fur Naturforschung Sect C A J Biosci 57:696-704

Filek M, Biesaga-Kościelniak J, Marcińska I, Krekule J, Machačkova I, Dubert F (2003a) The effects of electric current on flowering of grafted scions of non-vernalized winter rape. Biol Plant 46:625-628

Filek M, Gzyl B, Dudek A (2003b) The influence of phytohormones on the properties of wheat phospholipid monolayers at the water-air interface. Cell Mol Biol Lett 8:713-726

Filek M, Gzyl B, Laggner P, Kriechbaum M (2005a) Effect of indole3 -acetic acid on surface properties of the wheat plastid lipids. J Plant Physiol 162:245-252

Filek M, Hołda M, Machačkova I, Krekule J (2005b) The effect of electric field on callus induction with rape hypocotyls. Zeitschr fur Naturforschung Sect C A J Biosci 60:876-882

Filek M, Biesaga-Kościelniak J, Marcińska I, Krekule J, Machačkova I, Dubert F (2006) Electric current affects the rate of development in isolated apical parts of rape in vitro. Biol Plant 50:465-468

Filek M, Zembala M, Dudek A, Laggner P, Kriechbaum M (2007) Electric and structural studies of hormone interaction with chloroplast envelope membranes isolated from vegetative and generative rape. J Plant Physiol 164:861-867

Filek M, Zembala M, Hartikainen H, Miszalski Z, Kornaś A, Wietecka-Posłuszny R, Walas P (2009) Changes in wheat plastid membrane properties induced by cadmium and selenium in presence/absence of 2,4-dichlorophenoxyacetic acid. Plant Cell Tissue Organ Cult 96:19-28

Filek M, Gzyl-Malcher B, Zembala M, Bednarska E, Laggner P, Kriechbaum M (2010) Effect of selenium on characteristics of rape chloroplasts modified by cadmium. J Plant Physiol 167:28-339

Filek M, Walas S, Mrowiec H, Rudolphy-Skórska E, Sieprawska A, Biesaga-Kościelniak J (2012) Membrane permeability and micro- and macroelement accumulation in spring wheat cultivars during the short-term effect of salinity- and PEG-induced water stress. Acta Physiol Plant 34:985-995

Franco CR, Chagas AP, Jorge RA (2002) The influence of phytohormones on zeta potential and electrokinetic charges of winter wheat callus. Z Naturforsch 57:696-704

Galliard T (1968) Aspects of lipid metabolism in higher plants. I. Identification and quantitative determination of the lipids in potato tubers. Phytochemistry 7:1907-1914

Garidel P, Blume A (2005) 1,2-Dimyristoyl-sn-glycero-3-phosphoglycerol (DMPG) monolayers: influence of temperature, $\mathrm{pH}$, ionic strength and binding of alkaline earth cations. Chem Phys Lipids 138:50-59

Garidel P, Blume A, Hubner W (2000) A Fourier transform infrared spectroscopic study of the interaction of alkaline earth cations with the negatively charged phospholipid 1,2-dimyristoyl-snglycero-3-phosphoglycerol. Biochim Biophys Acta 1466:245-259 
Gibrat R, Grouzis JP, Rigaud J, Grignon C (1985) Electrostatic characteristics of corn root plasmalemma: effect on the $\mathrm{Mg}^{2+}$. ATPase activity. Biochim Biophys Acta 816:349-357

Gimmler H, Treffny B, Kowalski M, Zimmermann U (1991) The resistance of Dunaliella acidophila against heavy metals: the importance of the zeta potential. J Plant Physiol 138:708-771

Gniazdowska A, Szal B, Rychter AM (1999) The effect of phosphate deficiency on membrane phospholipid composition of bean (Phaseolus vulgaris L.) roots. Acta Physiol Plant 21:263-269

Gombos Z, Wada H, Hideg E, Murat N (1994) The unsaturation of membrane lipids stabilizes photosynthesis against heat stress. Plant Physiol 104:563-567

Gopal A, Lee KYC (2001) Morphology and collapse transitions in binary phospholipid monolayers. J Phys Chem B 105:10348-10354

Greń A, Barbasz A, Kreczmer B, Sieprawska A, Rudolphi-Skórska E, Filek M (2012) Protective effect of ascorbic acid after single and repetitive administration of cadmium in Swiss mice. Toxicol Mech Methods 22:597-604

Grigoriev D, Miller R, Wüstneck R, Wüstneck N, Pison U, Möhwald $\mathrm{H}$ (2003) A novel method to evaluate the phase transition thermodynamics of Langmuir monolayers. Application to DPPG monolayers affected by subphase composition. J Phys Chem B 107:14283-14288

Gringon C, Sentenac H (1991) $\mathrm{pH}$ and ionic conditions in the apoplast. Annu Rev Plant Physiol Plant Mol Biol 42:103-128

Guillot-Salomon T, de Virville JD, Aaron I, Alien MF, Cantrel C, Moreau F (1995) Lipid composition of intact functional mitochondria isolated from Arabidopsis thaliana suspension cultures. In: Kader JC, Mazliak P (eds) Plant Lipid Metab. Springer, Netherlands, pp 197-199

Gzyl B, Filek M, Dudek A (2004) Influence of phytohormones on polar and hydrophobic parts of mixed phospholipid monolayers at water/air interface. J Colloid Interface Sci 269:153-157

Gzyl-Malcher B, Filek M, Brezesinski G, Fischer A (2007) The influence of plant hormones on phospholipid monolayer stability. Zeitschr fur Naturforschung Sect C A J Biosci 62:55-60

Gzyl-Malcher B, Filek M, Makyla K, Paluch M (2008) Differences in surface behaviour of galactolipids originating from different kind of wheat tissue cultivated in vitro. Chem Phys Lipids 155:24-30

Gzyl-Malcher B, Filek M, Brezesinski G (2009) Influence of cadmium and selenate on the interactions between hormones and phospholipids. Langmuir 25:13071-13076

Gzyl-Malcher B, Zembala M, Filek M (2010) Effect of tocopherol on surface properties of plastid lipids originating from wheat calli cultivated in cadmium presence. Chem Phys Lipids 163:74-81

Gzyl-Malcher B, Filek M, Brezesinski G (2011) Mixed DPPC/ DPTAP monolayers at the air/water interface: influence of indolilo-3-acetic acid and selenate ions on the mono layer morphology. Langmuir 27:10886-10893

Harwood JL (1975) Lipid synthesis by germinating soya bean. Phytochemistry 14:1985-1990

Harwood JL (1980) Plant acyl lipids: structure, distribution and analysis. In: Stumpf PK (ed) The biochemistry of plants, Academic, New York, vol 4. Lipids: structure and function, pp 1-55

Harwood JL (1997) Plant lipid metabolism. In: Dey PM, Harborne JB (eds) Plant biochemistry. Academic, San Diego, pp 237-271

Harwood JL (1998) Involvement of chloroplast lipids in the reaction of plants submitted to stress. In: Siegenthaler PA, Murata N (eds) Lipids in photosynthesis structure, function and genetics. Kluwer Academic Publishers, The Netherlands, pp 287-302

Hawke J, Rumsby MG, Leech RM (1974) Lipid biosynthesis in green leaves of developing maize. Plant Physiol 53:555-561

He P, Fang K, Zou G, Peltonen JPK, Rosenholm JB (2002) Elasticity of Langmuir monolayer detected by dynamic oscillation method. Colloids Surf A 201:265-273
Hejnowicz Z, Trębacz K, Sievers A (1995) Temperature-dependent changes of electric-potential differences on opposite sides of the tepals of eranthis in relation to thermonastic responses. Plant Cell Environ 18:471-474

Hernandez LE, Cooke DT (1997) Modification of the root plasma membrane lipid composition of cadmium-treated Pisum sativum. J Exp Bot 48:1375-1381

Hetherington PR, Broughton HL, McKersie BD (1988) Ice-encasement injury to microsomal membranes isolated from winter wheat crowns. Plant Physiol 86:740-743

Hincha DK (2003) Effects of calcium-induced aggregation on the physical stability of liposomes containing plant glycolipids. Biochim Biophys Acta 1611:180-186

Honary S, Zahir F (2013) Effect of zeta potential on the properties of nano-drug delivery systems - a review (part 1). Trop J Pharm Res 12:255-264

Horváth I, Multhoff G, Sonnleitner A, Vígh L (2008) Membraneassociated stress proteins: more than simply chaperones. Biochim Biophys Acta 1778:1653-1664

Horváth I, Glatz A, Nakamoto H, Mishkind ML, Munnik T, Saidi Y, Goloubinoff P, Harwood JL, Vigh L (2012) Heat shock response in photosynthetic organisms: membrane and lipid connections. Prog Lipid Res 51:208-220

Hu JG, Granek R (1996) Buckling of amphiphilic monolayers induced by head-tail asymmetry. J Phys II Fr 6:999-1022

Hua T, Song-Nian Y (1998) Effect of different types of electrolyte on surface potential of liposome of PC and PC-cholesterol. Acta Phys Chim Sin 14:1043-1047

Huynh NT, Passirani C, Saulnier P, Benoit JP (2009) Lipid nanocapsules, A new platform for nanomedicine. Int J Pharm 379:201-209

Ibrahim MM, Abd El-Aal A, El-Dakak RM (2012) Evaluation of protein and lipid composition of plasma membrane of Zea mays L. Relative to copper and cadmium tolerance. J Bot 2nd international conference, 29-30 April, Minia Univ, Egypt, 1-18

Ishikawa S, Wagatsuma T (1998) Plasma membrane permeability of root-tip cells following temporary exposure to $\mathrm{Al}$ ions is a rapid measure of $\mathrm{Al}$ tolerance among plant species. Plant Cell Physiol 39:516-525

Jolliot A, Justin AM, Bimont E, Mazliak P (1982) Regulation by lipids of plant microsomal enzymes. Plant Physiol 70:206-210

Jouhet J, Maréchal E, Baldan B, Bligny R, Joyard J, Block MA (2004) Phosphate deprivation induces transfer of DGDG galactolipid from chloroplast to mitochondria. J Cell Biol 167:863-874

Jouve L, Engelmann F, Noirot M, Charrier A (1993) Evaluation of biochemical markers (sugar, proline, malondialdehyde and ethylene) for cold sensitivity in microcuttings of two coffee species. Plant Sci 91:109-116

Jurak M, Chibowski E (2010) Surface free energy and topography of mixed lipid layers on mica. Colloids Surf B 75:165-174

Jurak M, Miñones Conde J (2013) Characterization of the binary mixed monolayers of $\alpha$-tocopherol with phospholipids at the airwater interface. Biochim Biophys Acta 1828:2410-2418

Kacperska-Palacz A (1978) Mechanism of cold acclimation in herbaceous plants. In: Li PH, Sakai A (eds) Plant cold hardiness and freezing stress mechanisms and crop implications, vol 1003. Academic, New York, pp 139-153

Kaniuga Z, Sączyńska V, Miśkiewicz E, Garstka M (1999) Degradation of leaf polar lipids during chilling and post-chilling rewarming of Zea mays genotypes reflects differences in their response to chilling stress. The role of galactolipase. Acta Physiol Plant 21:45-56

Karcz W, Burdach Z (2002) A comparison of the effects of IAA and 4-Cl-IAA on growth, proton secretion and membrane potential in maize coleoptile segments. Z J Exp Bot 53:1089-1098 
Karcz W, Burdach Z (2007) Effect of temperature on growth, proton extrusion and membrane potential in maize (Zea mays L.) coleoptile segments. Plant Growth Regul 52:141-150

Karcz W, Kurtyka R (2007) Effect of cadmium on growth, proton extrusion and membrane potential in maize coleoptile segments. Biol Plant 51:713-719

Kendall EJ, McKersie BD, Stinson RH (1985) Phase properties of membranes following freezing injury in winter wheat. Can J Bot 63:2274-2277

Kinraide TB (1994) Use of a Gouy-Chapman-Stern model for membrane-surface electrical potential to interpret some features of rhizotoxicity. Plant Physiol 106:1583-1592

Kinraide TB (1998) Three mechanisms for the calcium alleviation of mineral toxicities. Plant Physiol 118:513-520

Kinraide TB (2003) The controlling influence of cell-surface electrical potential on uptake and toxicity of selenate $\left(\mathrm{SeO}_{4}{ }^{2-}\right)$. Plant Physiol 117:64-71

Kinraide TB, Wang P (2010) The surface charge density of plant cell membranes $(\sigma)$ : an attempt to resolve conflicting values for intrinsic $\sigma$. J Exp Bot 61:2507-2518

Kinraide TB, Ryan PR, Kochian LV (1992) Interactive effects of $\mathrm{Al}^{3+}, \mathrm{H}^{+}$, and other cations on root elongation considered in terms of cell-surface electrical potential. Plant Physiol 99:1461-1468

Kinraide TB, Yermiyahu U, Rytwo G (1998) Computation of surface electrical potentials of plant cell membranes. Plant Physiol 118:505-512

Kirby CW, McCallum JL, Fofana B (2011) A 1H NMR study of the fatty acid distribution in developing flax bolls before and after a cooking treatment. Can J Chem 89:1138-1142

Kirchner S (1996) Direct measurement of ion distribution between lipid membranes with X-ray diffraction. Biochim Biophys Acta 1279:181-189

Klein JW, Ware BR, Barclay G, Petty HR (1987) Phospholipid dependence of calcium ion effects on electrophoretic mobilities of liposomes. Chem Phys Lipids 43:13-23

Knobler CM, Desai R (1992) Phase transitions in monolayers. Annu Rev Phys Chem 43:207-236

Koca H, Bor M, Özdemir F, Türkan I (2007) The effect of salt stress on lipid peroxidation, antioxidative enzymes and proline content of sesame cultivars. Environ Exp Bot 60:344-351

Körner LE, Kjellbom P, Larsson C, Møller IM (1985) Surface properties of right side-out plasma membrane vesicles isolated frombarley roots and leaves. Plant Physiol 79:72-79

Koselski M, Trebacz K, Dziubińska H, Krol E (2008) Light- and dark-induced action potentials in Physcomitrella patens. Plant Signal Behav 3:13-18

Król E, Dziubińska H, Trębacz K (2004) Low-temperature-induced transmembrane potential changes in mesophyll cells of Arabidopsis thaliana, Helianthus annuus and Vicia faba. Physiol Plant 120:265-270

Kültz D (2005) Molecular and evolutionary basis of the cellular stress response. Annu Rev Physiol 67:225-257

Kundu S, Langevin D (2008) Fatty acid monolayer dissociation and collapse: effect of $\mathrm{pH}$ and cations. Colloids Surf A Physicochem Eng Asp 325:81-85

Kundu S, Datta A, Hazra S (2005) Effect of metal ions on monolayer collapses. Langmuir 21:5894

Kupisz K, Trebacz K (2011) Effect of cold and menthol on membrane potential in plants. Physiol Plant 141:352-360

Kurtyka R, Burdach Z, Karcz W (2011) Effect of cadmium and lead on the membrane potential and photoelectric reaction of Nitellopsis obtusa cells. Gen Physiol Biophys 30:52-58

Kutschera HL, Chaoa P, Deshmukha M, Rajana SS, Singha Y, Hua P, Josephb LB, Steina S, Laskinb DL, Sinkoa PJ (2010) Enhanced passive pulmonary targeting and retention of PEGylated rigid microparticles in rats. Int J Pharm 402:64-71

Laggner P, Filek M, Marcińska I, Szechyńska-Hebda M, Kriechbaum M (2003) X-ray structure investigations of winter wheat membrane systems. I. Influence of phytohormones on phospholipid orientation in non- and embryogenic cells. Plant Sci 165:265-270

Li L, Zhang H, Pan G (2014) Influence of zeta potential on the flocculation of cyanobacteria cells using chitosan modified soil. J Environ Sci. doi:10.1016/j.jes.2014.04.017

Lindberg S, Szynkier K, Greger M (1991) Aluminum effects on transmembrane potential in cells of fibrous roots of sugar beet. Plant Physiol 83:54-62

Lindsey K, Pullen ML, Topping JF (2003) Importance of plant sterols in pattern formation and hormone signalling. Trends Plant Sci 8:521-525

Liu Y, Liao T, Joseph DD (1995) A two-dimensional cusp at the trailing edge of an air bubble rising in a viscoelastic liquid. J Fluid Mech 304:321

Liu Y, Yan ECY, Zhao X, Eisenthal KB (2001) Surface potential of charged liposomes determined by second harmonic generation. Langmuir 17:2063-2066

Ma Y, Xie X, Zhuang Y, Zhou D, Cai L (2010) The role of surface charge in cationic liposome-induced antigen-presenting cell (APC) activation and viability. J Immunol 184:9821

Machačkova I, Krekule J, Filek M, Biesaga-Kościelniak J, Marcinska I (2004) Developmental effects of electric in thermo- and photoperiodic plants. Acta Physiol Plant 26:166-167

Macháčková I, Adamec L, Pospíšková-Nováková M, Krekule J (1989) The inhibitory action of an electric current on the flowering of short day plant Chenopodium rubrum L.- - timing and localization of the effect. In: Krekule J, Seidlová F (eds) Signals in plant development. SPB Academic Publishing, The Hague, pp 119-127

Mackender RO, Leech RM (1974) The galactolipid, phospholipid, and fatty acid composition of the chloroplast envelope membrane of Vicia faba L. Plant Physiol 53:496-502

Mady MM, Darwish MM (2010) Effect of chitosan coating on the characteristics of DPPC liposomes. J Adv Res 1:187-191

Magarkar A, Karakas E, Stepniewski M, Róg T, Bunker A (2012) Molecular dynamics simulation of PEGylated bilayer interacting with salt ions: a model of the liposome surface in the bloodstream. J Phys Chem B 116:4212-4219

Magarkar A, Dhawan V, Kallinteri P, Viitala T, Elmowafy M, Róg T, Bunker A (2014) Cholesterol level affects surface charge of lipid membranes in saline solution. Sci Rep 4:5005. doi:10.1038/ srep05005

Makino K, Yamada T, Kimura M, Oka T, Ohshima H, Kondo T (1991) Temperature- and ionic strength-induced conformational changes in the lipid head group region of liposomes as suggested by zeta potential data. Biophys Chem 41:175-183

Maltseva E, Shapovalov VL, Möhwald H, Brezesinski G (2006) Ionization state and structure of L-1,2-Dipalmitoylphosphatidylglycerol monolayers at the liquid/air interface. J Phys Chem B 110:919-926

Mamta S, Gupta SN, Saxena M (1987) Effect of electric field on mitosis in root tips of Allium cepa L. Cytologia 52:787-791

Marschner H (1995) Mineral nutrient of higher plants, 2nd edn. Academic Press, London

Martins Júnior RR, Oliveira MSC, Baccache MA, de Paula FM (2008) Effects of water deficit and rehydration on the polar lipid and membranes resistance leaves of Phaseolus vulgaris L Cv. Pérola. Braz Arch Biol Technol 51:361-367

McConnell HM (1991) Structures and transitions in lipid monolayers at the air-water interface. Annu Rev Phys Chem 42:171-195 
McKersie BD, Senaratna T, Walker MA, Kendall EJ, Hetherington PR (1988) Deterioration of membranes during aging in plants: evidence for free radical mediation. In: Noodén LD, Leopold AC (eds) Senescence and aging in plants. Academic, New York, pp 452-453

McLaughlin S, Whitaker M (1988) Cations that alter surface potentials of lipid bilayers increase the calcium requirement for exocytosis in sea urchin eggs. J Physiol 396:189-204

Meijer HJ, Munnik T (2003) Phospholipid-based signaling in plants. Annu Rev Plant Biol 54:265-306

Millar AA, Wrischer M, Kunst LV (1998) Accumulation of verylong-chain fatty acids in membrane glycerolipids is associated with dramatic alterations in plant morphology. Plant Cell 11:1889-1902

Miñones J Jr, Patino JMR, Miñones J, Dynarowicz-Latka P, Carrera C (2002) Structural and topographical characteristics of dipalmitoyl phosphatidic acid in Langmuir monolayers. J Colloid Interface Sci 249:388-397

Miñones J Jr, Dynarowicz-Łątka P, Miñones J, Rodriguez Patino JM, Iribarnegaray E (2003) Orientational changes in dipalmitoyl phosphatidyl glycerol Langmuir monolayers. J Colloid Interface Sci 265:380-385

Mittler R, Finka A, Goloubinoff P (2012) How do plants feel the heat? Trends Biochem Sci 37:118-125

Mizusawa N, Wada H (2012) The role of lipids in photosystem II. Biochim Biophys Acta 1817:194-208

Möhwald H (1993) Surfactant layers at water surfaces. Rep Prog Phys 56:653-685

Mól R, Filek M, Dumas C, Matthys-Rochon E (2004) Cytoplasmic calcium in silk trichomes after pollen grain reception and postpollination changes of the electric potential in pistil tissues of maize. Plant Sci 166:1461-1469

Møller IM, Kay CJ, Palmer JM (1984a) Electrostatic screening stimulates rate-limiting steps in mitochondrial electron transport. Biochem J 223:761-767

Møller IM, Lundborg T, Bérczi A (1984b) The negative surface charge density of plasmalemma vesicles from wheat and oat roots. FEBS Lett 167:181-185

Moore TS (1982) Phospholipid biosynthesis. Ann Rev Biochem 33:235-259

Moreau P, Bessoule JJ, Mongrand S, Testet E, Vincent P, Cassagne C (1998) Lipid trafficking in plant cells. Prog Lipid Res 37:371-391

Moreno C, Macias A, Prieto A, De La Cruz A, Valenzuela C (2012) Polyunsaturated fatty acids modify the gating of $\mathrm{Kv}$ channels. Front Pharmacol 3:163. doi:10.3389/fphar.2012.00163

Mozuraityte R, Rustad T, Storrø I (2006) Oxidation of cod phospholipids in liposomes: effects of salts, $\mathrm{PH}$ and zeta potential. Eur J Lipid Technol 108:944-950

Munné-Bosch S, Schwarz K, Leonor Alegre L (1999) Enhanced formation of a-tocopherol and highly oxidized abietane diterpenes in water-stressed rosemary plants. Plant Physiol 121:1047-1052

Murata N, Higashi SI, Fujimura Y (1990) Glycerolipids in various preparations of photosystem II from spinach chloroplasts. Biochim Biophys Acta 1019:261-268

Nag OK, Awasthi V (2013) Surface engineering of liposomes for stealth behavior. Pharmaceutics 5:542-569

Nagata T, Melchers G (1978) Surface charge of protoplasts and their significance in cell-cell interaction. Planta 142:235-238

Nechitailo G, Gordeev A (2001) Effect of artificial electric fields on plants grown under microgravity conditions. Adv Space Res 28:629-631

Nouairi I, Ammai WB, Youssef NB, Daoud DBM, Ghorbal MH, Zarrouk M (2006) Comparative study of cadmium effects on membrane lipid composition of Brassica juncea and Brassica napus leaves. Plant Sci 170:511-519
Obi I, Ichkawa Y, Kakutani T, Senda M (1989a) Electrophoretic studies on plant protoplasts. I. pH dependence of zeta potential of protoplasts from various sources. Plant Cell Physiol 30:439-444

Obi I, Ichkawa Y, Kakutani T, Senda M (1989b) Electrophoresis, zeta potential and surface charges of barley mesophyll protoplasts. Plant Cell Physiol 30:129-135

Obi I, Kakutani T, Imaizumi N, Ichikawa Y, Senda M (1990) Surface charge density of hetero-fused plant protoplasts: an electrophoretic study. Plant Cell Physiol 31:1031-1037

Oka K, Ikeshima H, Ishikawa H, Ohta E, Sakata M (1988) Surface charge density estimation of Vigna mungo protoplasts using a fluorescent dye, 9-aminoacridine. Plant Cell Physiol 29:771-775

Pali T, Garab G, Horvath LI, Kota Z (2003) Functional significance of the lipid-protein interface in photosynthetic membranes. Cell Mol Life Sci 60:1591-1606

Palta JP, Whitaker BD, Weiss LS (1993) Plasma membrane lipids associated with genetic variability in freezing tolerance and cold acclimation of Solanum species. Plant Physiol 103:793-803

Papernik LA, Kochian LV (1997) Possible involvement of aluminuminduced electrical signals in aluminum tolerance in wheat. Plant Physiol 115:657-667

Park HG, Han SI, Oh SY, Kang HS (2005) Cellular responses to mild heat stress. Cell Mol Life Sci 62:10-23

Patila S, Sandberg A, Heckert E, Self W, Sea S (2007) Protein adsorption and cellular uptake of cerium oxide nanoparticles as a function of zeta potential. Biomaterials 28:4600-4607

Pawlikowska-Pawlega B, Dziubińska H, Krol E, Trebacz K, JaroszWilkołazka A, Paduch R, Gawron A, Gruszecki WI (2014) Characteristics of quercetin interactions with liposomal and vacuolar membranes. Biochim et Biophys Acta Biomembr 1838:254-265

Pawlikowska-Pawlęga B, Trębacz K, Król E, Gawron A (2000) Effects of quercetin and verapamil on membrane potential in the liverwort Conocephalum conicum. Acta Physiol Plant 22:61-67

Pawlikowska-Pawlęga B, Król E, Trębacz K, Gawron A (2007) The influence of apigenin on membrane and action potential in the liverwort Conocephalum conicum. Acta Physiol Plant 29:143-149

Petelska AD, Figaszewski Z (2000) Effect of pH on the interfacial tension of lipid bilayer membrane. Biophys J 78:812-817

Pick U, Weiss M, Gounaris K, Barber J (1987) The role of different thylakoid glycolipids in the function of reconstituted chloroplast ATP synthase. Biochim Biophys Acta 891:28-39

Pilet PE, Hervé R, Senn A (1985) Zeta potential of protoplasts from gravireacting maize roots. Planta 162:17-22

Pillai P, St John JB (1981) Lipid composition of chloroplast membranes from weed biotypes differentially sensitive to triazine herbicides. Plant Physiol 68:585-587

Piotrowska G, Filek M, Kacperska A (2000) The effects of freezing on membrane electric potential in winter oilseed rape leaves. Acta Physiol Plant 22:69-75

Plank L, Dahl CE, Ware BR (1985) Effect of sterol incorporation on head group separation in liposomes. Chem Phys Lipids 36:319-328

Poincelot RP (1976) Lipid and fatty acid composition of chloroplast envelope membranes from species with differing net photosynthesis. Plant Physiol 58:595-598

Przymusiński R, Spychala M, Gwozdz EA (1991) Inorganic lead changes growth polypeptide pattern of lupin roots. Biochem Physiol Pflan 187:51-57

Pukacki PM (2004) The effect of industrial air pollution on membrane lipid composition of scots pine (Pinus sylvestris L.) needles. Acta Soc Bot Pol 73:187-191

Quartacci MF, Pinho C, Sgherri CLM, Navari-lzzo F (1995) Lipid composition and two wheat cultivars protein dynamics in 
thylakoids of differently sensitive to drought. Plant Physiol 108:191-197

Quartacci MF, Cosi E, Navari-Izzo F (2001) Lipids and NADPHdependent superoxide production in plasma membrane vesicles from roots of wheat grown under copper deficiency or excess. J Exp Bot 52:77-84

Quartacci MF, Baker AJM, Navari-Izzo F (2005) Nitrilotriacetateand citric acid-assisted phytoextraction of cadmium by Indian mustard (Brassica juncea (L.) Czernj, Brassicaceae). Chemosphere 59:1249-1255

Quinn PJ (1988) Regulation of membrane fluidity in plants. In: Barber J, Baker NR (eds) Physiological regulation of membrane fluidity, vol 3. Alan R Liss, New York, pp 293-321

Quinn PJ, Joo F, Vigh L (1989) The role of unsaturated lipids in membrane structure and stability. Prog Biophys Mol Biol 53:71-103

Rabinovich-Guilatt L, Couvreur P, Lambert G, Goldstein D, Benita S, Dubernet C (2004) Extensive surface studies help to analyse zeta potential data: the case of cationic emulsions. Chem phys lipid 131:1-13

Reidiboym-Talleux L, Grenier-De March G (1999) Lipid and fatty acid composition in non-embryogenic calli and embryogenic tissues in wild cherry (Prunus avium). Physiol Plant 105:513-520

Richter C, Dainty J (1990) Ion behavior in plant cell wall. III. Measurements of the mean charge density parameter in delignified Sphagnum russowii cell walls. Can J Bot 68:768-772

Rochester CP, Kjellbom P, Larsson C (1987a) Lipid composition of plasma membranes from barley leaves and roots, spinach leaves and cauliflower inflorescences. Physiol Plant 71:257-263

Roughan PG, Batt RD (1969) The glycerolipid composition of leaves. Phytochemistry 8:363-369

Routaboul J-M, Fischer S, Browse J (2000) Trienoic fatty acids are required to maintain chloroplast function at low temperature. Plant Physiol 124:1697-1705

Rudolphi-Skórska E, Filek M, Zembala M (2014a) Physicochemical aspects of reaction of ozone with galactolipid and galactolipidtocopherol layers. J Membr Biol 247:639-649

Rudolphi-Skórska E, Zembala M, Filek M (2014b) Mechanical and electrokinetic effects of polyamines/phospholipid interactions in model membranes. J Membr Biol 247:81-89

Saad SMI, Policova Z, Acosta EJ, Hair ML, Neumann AW (2009) Mixed DPPC/DPPG monolayers at very high film compression. Langmuir 25:10907-10912

Saint-Jalmes A, Gallet F (1998) Buckling in a solid Langmuir monolayer: light scattering measurementsand elastic model. Eur Phys J B 2:489

Sakamoto S, Nakahara H, Uto T, Shoyama Y, Shibata O (2013) Investigation of interfacial behavior of glycyrrhizin with a lipid raft model via an Langmuir monolayer study. Biochim Biophys Acta 1828:1271-1283

Sakurai I, Schen JR, Leng S, Ohashi S, Kobayashi M, Wada H (2006) Lipids in oxygen-evolving photosystem II complexes of cyanobacteria and higher plants. J Biochem 140:201-209

Salama KHA, Mansour MMF, Ali FZM, Abou-hadi AF (2007) NaClinduced changes in plasma membrane lipids and proteins of Zea mays L. cultivars differing in their response to salinity. Acta Physiol Plant 29:351-359

Sanchez J, Badia A (2003) Atomic force microscopy studies of lateral phase separation in mixed monolayers of dipalmitoylphosphatidylcholine and dilauroylphosphatidylcholine. Thin Solid Films 440:223-239

Schalke M, Krüger P, Weygand M, Lösche M (2000) Submolecular organization of DMPA in surface monolayers: beyond the twolayer model. Biochim Biophys Acta 1464:113-126
Schenkel LC, Bakovic M (2014) Formation and regulation of mitochondrial membranes. Hindawi Publishing Corporation. Int J Cell Biol ID 709828. doi: 10.1155/2014/709828

Schleiff E, Tien R, Salomon M, Soll J (2001) Lipid composition of outer leaflet of chloroplast outer envelope determines topology of OEP7. Mol Biol Cell 12:4090-4102

Schwertner HA, Biale JB (1973) Lipid composition of plant mitochondria and of chloroplasts. J Lipid Res 14:235-242

Sharma P, Jha AB, Dubey RS, Pessarakli M (2012) Reactive oxygen species, oxidative damage, and antioxidative defense mechanism in plants under stressful conditions. J Bot, Article ID 217037. doi: $10.1155 / 2012 / 217037$

Sheppard AJ, Iverson JL, Weihrauch JL (1978) Composition of selected dietary fats, oils, margarines, and butter. In: Kuksis A (ed) Handbook of Lipid Research. vol 1. Fatty acids and glycerides. Plenum Press, New York, pp 341-379

Shiao TY, Shiao MS (1989) Determination of fatty acid composition of triacylglycerols by high resolution NMR spectroscopy. Bot Bull Acad Sin 30:191-199

Shomer I, Novacky AJ, Pike SM, Yermiyahu U, Kinraide TB (2003) Electrical potentials of plant cell walls in response to the ionic environment. Plant Physiol 133:411-422

Sikorska E, Kacperska A (1980) Phospholipid biosynthesis in winter rape plants during the winter season. Bull Acad Pol Des Sci Ser Des Sci Biol 28:191-194

Sikorska E, Kacperska A (1982) Modification on phospholipase D activity during frost hardening of winter rape plants. In: Wintermans JFGM, Kuiper PCJ (eds) Biochemistry and metabolism of plant lipids. Elsevier, Amsterdam, pp 415-418

Silva RF, Zaniquelli MED, Serra OA, Torriani IL, de Castro SGC (1998) Europium and terbium carboxylate interactions in monolayers and Langmuir-Blodgett films. Thin Solid Films 324:245-252

Singer SJ (1974) The molecular organization of membranes. Ann Rev Biochem 43:805-833

Smolenska-Sym G, Kacperska A (1994) Phosphatidylinositol metabolism in low temperature-affected winter oilseed rape leaves. Physiol Plant 91:1-8

Smolenska-Sym G, Kacperska A (1996) Inositol 1,4,5-trisphosphate formation in leaves of winter oilseed rape plants in response to freezing, tissue water potential and abscisic acid. Physiol Plant 96:692-698

Sparr E, Ekelund K, Engblom J, Engström S, Wennerström H (1999) An AFM study of lipid monolayers. 2. Effect of cholesterol on fatty acids. Langmuir 15:6950-6955

Sperling P, Heinz E (2003) Plant sphingolipids: structural diversity, biosynthesis, first genes and functions. Biochim Biophys Acta 1632:1-15

Stefanov K, Popova I, Kamburova E, Pancheva T, Kimenov G, Kuleva L, Popov S (1993) Lipid and sterol changes in Zea mays caused by lead ions. Phytochemistry 33:47-51

Stefanov K, Seizova K, Popova I, Petkov VL, Kimenov G, Popov S (1995) Effects of lead ions on the phospholipid composition in leaves of Zea mays and Phaseolus vulgaris. J Plant Physiol 147:243-246

Suhayda CG, Giannini JL, Briskin DP, Shannon MC (1990) Electrostatic changes in Lycopersicum esculentum root plasma membrane resulting from salt stress. Plant Physiol 93:471-478

Sui N, Han G (2014) Increases of unsaturated fatty acids in membrane lipids protects photosystem II from photoinhibition under salinity in different halophytes. J Agric Sci 6:251-264

Sumorek A, Pietrzyk W (1999) Influence of electric filed on the speed of convetive removal of water from wheat grain. Int Agrophys 13:509-513

Szarek I, Trebacz K (1999) The role of light-induced membrane potential changes in guttation in gametophytes of Asplenium trichomanes. Plant Cell Physiol 40:1280-1286 
Testerink Ch, Munnik T (2005) Phosphatidic acid: a multifunctional stress signaling lipid in plants. Trends Plant Sci 10:1360-1385

Toumi I, Gargouri M, Nouairi I, Moschou PN, Salem-Fnayou AB, Mliki A, Zarrouk M, Ghorbel A (2008) Water stress induced changes in the leaf lipid composition of four grapevine genotypes with different drought tolerance. Biol Plant 52:161-164

Trębacz K, Tarnecki R, Zawadzki T (1989) Characteristic of the lightinduced generator potentials in the liverwort Concephalum conicum. Physiol Plant 75:20-23

Trębacz K, Dziubińska H, Król E (2006) Electrical signals in longdistance communication in plants In: Baluska F, Mancuso S, Volkmann D (eds) Conference: 1st symposium on plant neurobiology, Florence, Italy, 277-290

Tseng LP, Liang HJ, Chung TW, Huang YY, Liu DZ (2007) Liposomes incorporated with cholesterol for drug release triggered by magnetic field. J Med Biol Eng 27:29-34

Uemura M, Joseph RA, Steponkus PL (1995) Cold acclimation of Arabidopsis thaliana. Effect on plasma membrane lipid composition and freeze-induced lesions. Plant Physiol 109:15-30

Vaknin D, Krüger P, Lösche M (2003) Anomalous X-ray reflectivity characterization of ion distribution at biomimetic membranes. Phys Rev Lett 90:178102-178104

Verma VS, Singh RA, Yadav RA (1988) Effect of electric treatment of crop soil on yield and yield attributes of wheat. Farm Sci J 3:92-96

Vigh L, Escribá PV, Sonnleitner A, Sonnleitner M, Piotto S, Maresca B, Horváth I, Harwood JL (2005) The significance of lipid composition for membrane activity: new concepts and ways of assessing function. Pro Lipid Res 44:303-344

Vigh L, Horváth I, Maresca B, Harwood JL (2007a) Can the stress protein response be controlled by 'membrane-lipid therapy'? Trends Biochem Sci 32:357-363

Vigh L, Török Z, Balogh G, Glatz A, Piotto S, Horváth I (2007b) Membrane-regulated stress response: a theoretical and practical approach. Adv Exp Med Biol 594:114-131

Vollhardt D (1993) Nucleation and growth in supersaturated monolayers. Adv Colloid Interface Sci 47:1-23

Vollhardt D, Fainerman VB, Siegel S (2000) Thermodynamic and textural characterization of DPPG phospholipid monolayers. J Phys Chem B 104:4115-4121

Wagatsuma T, Akiba R (1989) Low surface negatively of root protoplasts from aluminium-tolerant plant species. Soil Sci Plant Nutr 35:443-452

Wang X (2002) Phospholipase D in hormonal and stress signaling. Curr Opin Plant Biol 5:408-414

Wang P, Zhou D, Kinraide TB, Luo X, Li L, Li D, Zhang H (2008) Cell membrane surface potential $(\psi 0)$ plays a dominant role in the phytotoxicity of copper and arsenate. Plant Physiol 148:2134-2143

Wędzony M, Filek M (1996) Changes of electric potential in wheat pistils induced by pollination. Acta Soc Bot Pol 65:97-100

Wędzony M, Filek M (1998) Changes of electric potential in pistils of Petunia hybrida Hort. and Brassica napus L. during pollination. Acta Physiol Plant 20:291-297

Welti R, Wang X (2004) Lipid species profiling: a high-throughput approach to identify lipid compositional changes and determine the function of genes involved in lipid metabolism and signaling. Curr Opin Plant Biol 7:337-344

Welti R, Li W, Li M, Sang Y, Biesiada H, Zhou HE, Rajashekar CB, Williams TD, Wang X (2002) Profiling membrane lipids in plant stress responses. Role of phospholipase D in freezing-induced lipid changes in Arabidopsis. J Biol Chem 277:31994-32002
Whitaker BD (1986) Fatty-acid composition of polar lipids in fruit and leaf chloroplasts of " $16: 3$ " - and " $18: 3$ " - plant species. Planta 169:313-319

Wilson JM, Crawford RMM (1974) The acclimatization of plants to chilling temperatures in relation to the fatty-acid composition of leaf polar lipods. New Phytol 73:805-820

Wintermans JFGM (1960) Concentrations of phosphatides and glycolipids in leaves and chloroplasts. Biochim Biophys Acta 44:49-54

Wu F, Yang Z, Su X, Gong Y, Kuang T (2005) Molecular reorganization induced by $\mathrm{Ca}^{2+}$ of plant photosystem I reconstituted into phosphatidylglycerol liposomes. Chem Phys Lipids 136:73-82

Rochester CP, Kjellbom P, Andersson B, Larsson C (1987b) Lipid composition of plasma membranes isolated from light-grown barley (Hordeum vulgare) leaves: identification of cerebroside as a major component. Arch Biochem Biophys 255:385-391

Yazdanian M, Yu H, Zografi G (1990) Ionic interactions of fatty acid monolayers at the air/water interface. Langmuir 6:1093-1098

Yermiyahu U, Nir S, Ben-Hayyim G, Kafkafi U (1994) Quantitative competition of calcium with sodium or magnesium for sorption sites on plasma membrane vesicles of melon (Cucumis melo L.) root cells. J Membr Biol 138:55-63

Yermiyahu U, Brauer DK, Kinraide TB (1997a) Sorption of aluminium to plasma membrane vesicles isolated from roots of Scout 66 and Atlas 66 cultivars of wheat. Plant Physiol 115:1119-1125

Yermiyahu U, Rytwo G, Brauer DK, Kinraide TB (1997b) Binding and electrostatic attraction of lanthanum $\left(\mathrm{La}^{3+}\right)$ and aluminium $\mathrm{Al}^{3+}$ to wheat root plasma membranes. J Memb Biol 159:239-252

Yoshida S (1978) Phospholipid degradation and its control during freezing of plant cells. In: Li PH, Sakai A (eds) Plant cold hardiness and freezing stress mechanisms and crop implications, vol 1003. Academic, New York, pp 117-139

Zamani S, Bybordi A, Khorshidi MB, Nezami T (2010) Effects of $\mathrm{NaCl}$ salinity levels on lipids and proteins of canola (Brassica Napus L.) cultivars. Adv Environ Biol 4:397-403

Zawadzki T, Trębacz K (1982) Action-potentials in Lupinus angustifolius L shoots. Propagation of action-potential in the stem after the application of mechanical block. P J Exp Bot 33:100-111

Zawadzki T, Trębacz K (1985) Extracellular and intracellular measurements of action-potentials in the liverwort Conocephalum- conicum. Physiol Plant 64:477-481

Zhang G, Slaski JJ, Archambault DJ, Taylor GJ (1997a) Alteration of plasma membrane lipids in aluminum-resistant and aluminumsensitive wheat genotypes in response to aluminum stress. Physiol Plant 99:302-308

Zhang H, Hashinaga F, Zhang H (1997b) Effect of high electric field on the quality of Satsuma mandarin fruits. J Soc High Tech Agri 9:107-113

Zhang H, Hashinaga F, Zhang H (2000) Effect of high electric fields on the germination and early growth of some vegetable seeds. Jpn Soc Horti Sci 66:347-352

Zhang Q, Smith FA, Sekimoto H, Reid RJ (2001) Effect of membrane surface charge on nickel uptake by purified mung been root protoplasts. Planta 213:788-793

Zotova TV, Arslanov VV, Gagina IA (1998) Monolayers and Langmuir-Blodgett films of yttrium stearate. Thin Solid Films 326:223-226 